\title{
Szemle
}

\section{AZ ÉRZELMI FELDOLGOZÁS VIZSGÁLATA A FIATALKORI PSZICHOPÁTIÁS VONÁSOK VONATKOZÁSÁBAN: ÁTTEKINTŐ TANULMÁNY}

\author{
SZABÓ EDINA ${ }^{1,2,3}$ - KÖKÖNYEI GYÖNGYI ${ }^{2,4,5}$ \\ ${ }^{1}$ ELTE Eötvös Loránd Tudományegyetem Pszichológiai Doktori Iskola \\ ${ }^{2}$ ELTE Eötvös Loránd Tudományegyetem Pszichológiai Intézet \\ ${ }^{3}$ MTA-SE Neuropszichofarmakológiai és Neurokémiai Kutatócsoport, Magyar Tudományos \\ Akadémia, Semmelweis Egyetem, Budapest \\ ${ }^{4}$ SE-NAP2 Genetikai Agyi Képalkotó Migrén Kutatócsoport, Semmelweis Egyetem \\ ${ }^{5}$ Semmelweis Egyetem Gyógyszerhatástani Intézet \\ E-mail: kokonyei.gyongyi@ppk.elte.hu
}

Beérkezett: 2017. december 12. - Elfogadva: 2018. április 26.

\begin{abstract}
Az elmúlt években a pszichopátiára jellemző érzelmi deficit kiemelkedó figyelmet kapott. Különösen a pszichopátiás zavar affektív komponense, az ún. rideg-érzéketlen (callous-unemotional, CU) vonások kerültek elótérbe, melyet a pszichopátia gyermekkori elốzményeiként is vizsgálnak. Több empirikus kutatás is alátámasztja, hogy a CU vonásokkal jellemezhetố antiszociális fiatalok - akárcsak a felnôtt pszichopaták - nehézséget mutatnak az érzelmi ingerek, különösen a negatív, distresszkeltô jelzések felismerésében és feldolgozásában. Jelen áttekintố tanulmány célja, hogy ismertesse, valamint rendszerezze azokat az elméleteket és vizsgálati módszereket, melyek erre a sajátos érzelmi zavarra vonatkoznak. A témában végzett vizsgálatok ugyanis meglehetôsen eltérô feladatokkal, illetve mintával dolgoznak, ami megnehezíti az eredmények összehasonlítását. Mindazonáltal úgy tünik, hogy a fiatalkori CU vonásokra jellemzố érzelmi deficit a viselkedésbeli, a pszichofiziológiai, illetve a neurológiai válaszokban is megmutatkozik, ami a kora gyermekkori prevenció és intervenció fontosságára hívja fel a figyelmet, különös tekintettel az érzelmi feldolgozást fejlesztô programokra.
\end{abstract}

Kulcsszavak: pszichopátia, rideg-érzéketlen (CU) vonások, érzelmi feldolgozás, gyerekkor 


\section{BEVEZETÉS}

Jelen tanulmány célja, hogy áttekintést nyújtson a gyermekkori pszichopátiás vonások és az érzelmi feldolgozás vizsgálatának kutatási irányairól, illetve módszertanáról. A következókben elôbb ismertetjük a pszichopátia fogalmát, annak gyermekkori elôzményeit, majd röviden áttekintjük azokat az elméleteket, melyek a pszichopátia magyarázatában az érzelmi folyamatok zavarára helyezik a hangsúlyt. Ezt követôen az érzelmi feldolgozás vizsgálatának módszereit tárgyaljuk, rámutatva azok elônyeire, hátrányaira, illetve azokra a lehetséges kutatási irányokra, melyeket az eredmények alapján fontosnak találtunk.

\section{A PSZICHOPÁTIA FOGALMA ÉS JELENTŐSÉGE}

A pszichopátiás zavar különbözô affektív (pl. empátia és lelkiismeret-furdalás hiánya), interperszonális (pl. manipuláció, nárcizmus) és viselkedéses jegyekkel (pl. felelôtlenség, impulzivitás, korai és átfogó antiszociális viselkedés) írható körül (Cleckley, 1941; Cooke és Michie, 2001; Hare, 2003). Míg a börtönön kívüli, normál populációban „csak” 1\%-ra, a börtönökben pedig 10-25\%-ra tehető a pszichopátia elófordulása, a pszichopaták lényegesen nagyobb arányban mutatnak erôszakos és kriminális viselkedést (Hare, 1996). A nem pszichopata bûnözôkhöz képest több, illetve többféle büncselekményt követnek el, fiatalabb életkorban jelenik meg nálunk a deviáns viselkedés, és a visszaesések kockázata is magasabb náluk (Gretton, Hare és Catchpole, 2004; Hare, Strachan és Forth, 1993; Harris, Rice és Cormier, 1991; Hemphill, Hare és Wong, 1998).

A pszichopátia mérésében „aranystandardnak” számító mérôeszköz, a Pszichopátia Tulajdonságlista (Psychopathy Checklist-Revised; PCL-R; Hare, 2003) alapján a zavar tünetei legalább két csoportba sorolhatók. Míg az elsố (szociális deviancia) faktor a pszichopátia viselkedéses jellemzőit öleli fel, addig a második (affektív/interperszonális) faktor az érzelmi deficitet ragadja meg. Újabb megközelítések szerint azonban a pszichopátiát leginkább három (affektív, interperszonális és viselkedéses jellemzók; Cooke és Michie, 2001) vagy négy faktor (affektív, interperszonális, viselkedéses és antiszociális jegyek; Hare és Neumann, 2005; Neumann, Hare és Newman, 2007; Neumann, Vitacco, Hare és Wupperman, 2005) segítségével lehet meghatározni.

Az elmúlt években ugyanakkor a pszichopátia affektív faktora, vagyis az ún. ridegérzéketlen vonások (callous-unemotional traits; CU traits; továbbiakban CU vonások) kerültek leginkább előtérbe. Ide tartozik a bûntudat és az empátia hiánya, vagy az érzelmi sekélyesség, melyek a jól ismert pszichopátiakoncepciók legfontosabb ismertetôjegyei (Cleckley, 1941; Hare, 1980). Tulajdonképp ezek a vonások különböztetik meg a pszichopata búnözôket más antiszociális viselkedést mutató, búnelkövetô személyektől. 


\section{A PSZICHOPÁTIA GYERMEKKORI ELŐZMÉNYEI}

Már az 1940-es években felvetôdött az a gondolat, hogy a pszichopátia bizonyos jellemzői gyermekkorban is megmutatkozhatnak (Cleckley, 1941; Karpman, 1949, 1950; McCord és McCord, 1964), de ezeket a vonásokat csak a kilencvenes évek elején kezdték el szisztematikusan vizsgálni. Mára különösen népszerúvé vált az az irányzat, mely kifejezetten a CU vonások gyermekkori elôzményeire, gyökereire koncentrál (Frick, Bodin és Barry, 2000). Ez a megközelítés Paul Frick nevéhez fúződik, aki empirikus vizsgálataiban három olyan személyiségdimenziót azonosított (az antiszociális viselkedés mellett), melyek megfeleltethetôk a felnôttkori pszichopátiás vonásoknak: a CU vonásokat, a nárcizmust és az impulzivitást (Frick és mtsai, 2000; Vitacco, Rogers és Neumann, 2003). Bár mindhárom vonás magas szintjével jellemezhetôkk azok a fiatalok, akik súlyosan erôszakos és antiszociális magatartást mutatnak, úgy túnik, hogy a CU vonások jelenléte a legmeghatározóbb (összefoglalóért lásd: Frick, Ray, Thornton és Kahn, 2014a; Frick, Ray, Thornton és Kahn, 2014b; Frick és White, 2008).

Bizonyított, hogy azok a gyerekek és serdülôk, akik viselkedési problémákat, illetve CU vonásokat egyaránt mutatnak - az antiszociális fiataloknak kb. 1/3-a (Christian, Frick, Hill, Tyler és Frazer, 1997) -, jóval súlyosabb és tartósabb viselkedési problémákkal jellemezhetôk, mint a CU vonásokkal nem rendelkezó antiszociális társaik. Ezt az összefüggést búnelkövetô (Kruh, 2005; Vincent, Vitacco, Grisso és Corrado, 2003), klinikai (Christian és mtsai, 1997), illetve normál, egészséges fiatalok mintájában (Bozsik és mtsai, 2013; Frick és mtsai, 2003; Marsee, Silverthorn és Frick, 2005; Pardini és Fite, 2010; Pataky és mtsai, 2011) is sikerült kimutatni. A két csoport továbbá az antiszociális viselkedés hátterében álló genetikai és környezeti hatások mértékében is különbözik: a viselkedési problémák örökletessége (heritabilitása) jóval magasabb a CU vonások jelenléte esetében (Viding, Blair, Moffitt és Plomin, 2005; Viding, Frick és Plomin, 2007).

A CU vonások fontosságát igazolja az is, hogy a Mentális Rendellenességek Diagnosztikai és Statisztikai Kézikönyvének legújabb, ötödik kiadásában is szerepelnek (DSM-5; American Psychiatric Association, 2013): „korlátozott proszociális érzelmek” néven a viselkedési zavar diagnosztikus kategória egyik jelölőjeként jelennek meg. Fontos hangsúlyozni azonban, hogy a CU vonások esetében nem beszélhetünk egyezményesen elfogadott klinikai határértékekrôl. Több kutató érvel amellett, hogy a pszichopátiához köthetô személyiségvonásokat inkább dimenzióként, mintsem kategorikus (vagy taxonómikus) konstruktumként érdemes kezelni (Edens, Marcus, Lilienfeld és Poythress, 2006; Guay, Ruscio, Knight és Hare, 2007; Herpers és mtsai, 2017). Vagyis ezek a jellemzốk jobban értelmezhetốk, ha egy kontinuum mentén vizsgálják azokat, ahol az egyes személyek a vonások mértékében különböznek egymástól.

\section{AZ ÉRZELMI FELDOLGOZÁS ZAVARAI}

Az elmúlt 50 évben a pszichopátiával kapcsolatos vizsgálatokat olyan elméletek és klinikai leírások vezérelték, melyek az érzelmi deficitet a pszichopátia központi jellemzôjének tartják. Hervey Cleckley (1941), a pszichopátiás zavar elsố szisztematikus leírója 
is megfogalmazta, hogy a pszichopatáknál megfigyelhetô moralitás hiánya a korai szocializációjukra, egész pontosan a normál érzelmi élmények hiányára vezethetô vissza. Több kutató is támogatja azt a nézetet, hogy a pszichopátia kialakulásában valójában az érzelmi folyamatok zavarának van döntô jelentôsége (Blair, 1995; Blair, Mitchell és Blair, 2005; Herba és mtsai, 2007; Patrick, 1994).

Az egyik legkorábbi elmélet, az ún. alacsony félelem modell (low-fear model; Lykken, 1957; Patrick, 1994) szerint a pszichopaták a fenyegetéssel és büntetéssel kapcsolatos jelzések feldolgozásában mutatnak zavart, mely végsố soron a morális szocializációjuk sikertelenségéhez vezet. Az elmélet értelmében bár a pszichopaták képesek bizonyos érzelmek átélésre, a félelem tudatos élményére való csökkent képesség és a szorongás hiánya jellemzi óket, mely az averzív ingerekre, a büntetésre adott automatikus válaszok deficitjében mutatkozik meg. A megközelítést számtalan kutatási eredmény igazolja (pl. a passzív elkerüló tanulás nehézsége, a fenyegetésre adott csökkent válaszkészség; Lykken, 1995; Patrick, Bradley és Lang, 1993), mégis úgy tûnik, hogy a szocializációban inkább az empátiának, és nem a büntetésnek, a félelmi kondicionálásnak van elsôdleges szerepe (Hoffman, 1984).

Egyre elterjedtebb az a nézet, miszerint a pszichopaták interperszonális problémái és károkozó viselkedése (pl. bûnelkövetô és erôszakos magatartás, mások kihasználása, kizsákmányolása) abból fakad, hogy képtelenek mások érzéseit megfelelően detektálni (Blair, 2005). James Blair modellje, az ún. integrált érzelmi rendszerek elmélet szerint (integrated emotional system model; korábbi változata: erôszak gátlási mechanizmus modell; violence inhibition model; Blair, 1995) míg a másokon látott distressz jelzések (pl. a félelem és a szomorúság) átélése meggátolhatja az antiszociális viselkedést, addig ezen kifejezések feldolgozásának zavarai agresszív viselkedéshez vezethetnek. Az integrált érzelmi rendszerek elmélet (túlmutatva az egységes félelmi rendszer feltételezésén) már különbséget tesz az averzív inger-megerôsítés és inger-válasz tanulás között, rámutatva arra, hogy a pszichopátiában az elóbbi sérült, ami akár a jutalmazó inger-megerôsítés kapcsolat kialakulását is érintheti (Blair, 2005). A modell az érzelmi zavar hátterében a limbikus rendszer, egész pontosan az amygdala (a félelmi válasz központjának) diszfunkcionális múködését feltétezi. Ez a régió kulcsszerepet játszik abban, hogy (az inger-megerôsítéses tanuláson keresztül) a károkozó viselkedés és az áldozaton látott distressz (mint averzív megerôsítés) végül összekapcsolódjon (Blair, 2007).

Blair (2005) elmélete tehát az averzív, distresszkeltô ingerek átélésének és feldolgozásának nehézségét hangsúlyozza, ami szorosan kötôdik az ún. instrumentális (vagy más néven proaktív) agresszió megjelenéséhez is. Blair megközelítése szerint a pszichopátiás zavar (egyedülálló módon) magasabb kockázatot jelent a proaktív és reaktív típusú agresszióra is (Blair, 2010). Míg a proaktív agressziót egy meghatározott cél (pl. pénz, szociális státusz) elérése érdekében, mások distresszét, fájdalmát figyelmen kívül hagyva hajtják végre („hidegvérû” agresszió), addig a reaktív agresszió impulzív, heves viselkedéses válasz, mely rendszerint haraggal és a szociálisan fenyegetô jelzések (pl. a haragot kifejezô arc) fokozottabb feldolgozásával társulhat („forrófejú” agreszszió) (Berkowitz, 1993; Blair, 2010; Dodge, 1991).

A pszichopátiára jellemzô érzelmi zavar ugyanakkor jól értelmezhetô egy újabb elmélet, az empátia ún. önmagunk-mások modelljének keretében is (self to other model of empathy; Bird és Viding, 2014). A megközelítés szerint bár a pszichopaták 
megfelelố fogalmi reprezentációval bírnak a másokon látott distressz jelzésekrôl, és képesek is azokat megnevezni (igaz, lassabban és több hibával, mint az egészséges személyek), mások distresszére atipikus érzelmi választ mutatnak, az érzelmi arousal hiánya jellemzi óket. Az elmélet értelmében a tudatelméleti rendszerük, vagyis az a képességük, hogy mások mentális állapotáról gondolkodjanak, intakt, miközben az affektív jelzésekre vonatkozó osztályozási rendszerük sérült. Ez utóbbi rendszer megfelelô múködése szükséges ahhoz, hogy az érzelmi rezonancia kialakuljon, ami pedig az empátia nélkülözhetetlen feltétele (lásd 1. ábra). A modell szerint az érzelmi rezonancia a saját belsô érzelmi állapot és az adott érzelmi állapot másokon látott jelzéseinek ismétlốdô társítása során jöhet létre. Magas pszichopátiás vonások mellett viszont a distressz érzésének csökkent megtapasztalása jellemzô, ami tehát az érzelmi rezonancia hiányához vezethet. Voltaképpen ez az elmélet is a distressz átélésének, illetve az ezzel kapcsolatos jelzések feldolgozásának zavarát emeli ki a pszichopátia magyarázatában.

Az eddigi ismertetett modellektôl eltérôen a válaszmoduláció elmélet (response modulation hypothesis; Newman és Lorenz, 2003) viszont azt feltételezi, hogy a pszichopaták csak akkor mutatnak nehézséget az affektív információk feldolgozásában, ha az a figyelmi fókuszukon kívül esik. A megközelítés szerint a pszichopaták képtelenek a célirányos viselkedéshez képest perifériás információk felé fordítani a figyelmüket (pl. félelmet keltô, de a célok szempontjából irreleváns ingerek felé), így az adott viselkedési forma merev fenntartása jellemzi óket (válaszperszeveráció). Az elmélet tehát nem az affektív reaktivitás, hanem a figyelem zavarára épít: magasabb szintú figyelmi folyamatok határozzák meg az érzelmi feldolgozás minôségét (így az amygdala aktivációjának szintjét is) (Baskin-Sommers, Curtin és Newman, 2011; Newman, Curtin, Bertsch és Baskin-Sommers, 2010).

A válaszmoduláció modell egybecseng Dadds és munkatársainak megközelítésével is, amely - Blair modelljéhez hasonlóan - ugyancsak az amygdala zavarára épít, de amellett foglal állást, hogy a pszichopátiás zavarban a szociálisan releváns jelzésekre, pontosabban a szemekre, a tekintetre adott figyelmi válasz sérült (Dadds és mtsai, 2006; Dadds, El Masry, Wimalaweera és Guastella, 2008). A pszichopátia hátterében

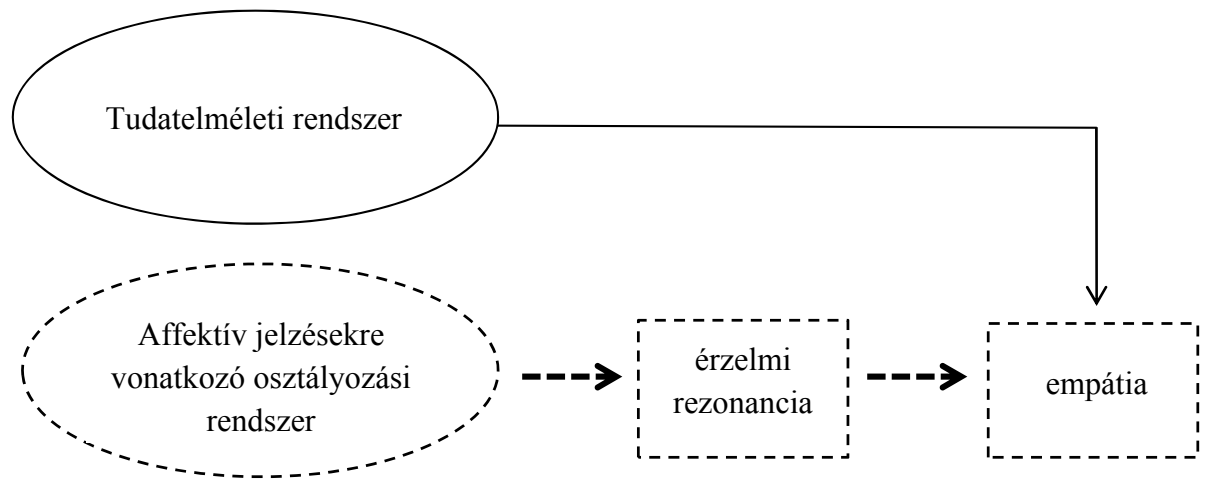

1. ábra. A pszichopátiára jellemzô érzelmi zavar magyarázata az empátia ún. önmagunk-mások modelljének (Bird és Viding, 2014) keretében. A pszichopátiában érintett területeket szaggatott vonallal jeleztük. 
tehát (a félelmet kifejezô jelzések felismerési zavara helyett) azoknak az automatikus mechanizmusoknak a diszfunkcióját feltételezik, amelyek az emberi arc kritikus érzelmi jegyei felé terelik a figyelmet. A megközelítés szerint ez a zavar a szülö-gyerek közötti interakciókra is kihathat (csökkent szemkontaktus), ami végsố soron affektív deficithez, az empátia és a lelkiismeret-furdalás hiányához vezethet (Dadds, Jambrak, Pasalich, Hawes és Brennan, 2011). Az elmélet értelmében tehát a pszichopátiás vonások átfogóbb figyelmi zavarral társulnak, ami többféle érzelem feldolgozását is érintheti (nemcsak a félelem jelzéseit), illetve (az eddig ismertetett elméletekkel ellentétben) csak az arckifejezések esetében nyilvánulhat meg.

Összefoglalva megállapítható, hogy a félelemnélküliség, a félelmi deficit, a „félelmi vakság” kulcsszerepet játszik számos pszichopátiával kapcsolatos leírásban és elméletben is (Cleckley, 1941; Lykken, 1957; Patrick, 1994; Patrick, Fowles és Krueger, 2009). A félelmet azonban afféle „ernyőfogalomként” használja a szakirodalom, így gyakran nem világos, hogy a pszichopátiában valójában a félelem átélése és/vagy a félelmet keltô, fenyegetố ingerekre adott automatikus válaszok sérültek. A következô alfejezetben röviden kitérünk arra, hogy a félelemnek pontosan milyen összetevôi lehetnek, miért lényeges megkülönböztetni ezeket egymástól.

\section{A félelem fogalma}

A pszichopátia kutatásában egyrészt rendkívül fontos a félelem és a szorongás érzésének megkülönböztetése egymástól (szorongás ugyanis jellemezheti az ún. másodlagos típusú pszichopatákat; összefoglalóért lásd: Szabó, Galambos, Szabó és Kökönyei, 2016). Bár mindkét érzelem központi eleme a jövoobeli fenyegetés anticipációja és az arra való felkészülés, a félelem átmeneti választ jelent egy jól beazonosítható, közelgó veszélyre, miközben a szorongás egy hosszan tartó érzelmi állapot, ami egy lehetséges, de elôre nem látható (azaz bejósolhatatlan) fenyegetés hatására lép fel. A félelmet rövid távú arousal jellemzi, ami válaszra motiválja a személyt (pl. támadj-vagy-menekülj viselkedésreakció, lefagyás), a szorongás viszont tartós arousalszinttel írható körül, amely a veszélyforrás jelenléte nélkül, illetve annak eltávolítása után is fennmaradhat (Barlow, 2000; Grillon, 2008).

Másfelôl lényeges, hogy különbséget tegyünk a félelem tudatos érzése és a fenyegetésre mutatott, automatikus testi válaszok között (LeDoux, 2013, 2014). Az a rendszer ugyanis, amely a fenyegetô ingerekre reagál, nem egyezik meg azzal, ami a félelem tudatos megtapasztalását lehetôvé teszi. A fenyegetésre adott automatikus, defenzív válasz nem feltétlen vezet a félelem átéléséhez, hátterükben eltérô agyi területek is állnak (Hoppenbrouwers, Bulten és Brazil, 2016).

A fenyegetésre mutatott, beépített testi reakció mérhetô belsô állapotváltozás (pl. bôrvezetés, légzés, szívritmus) vagy külsôleg is megfigyelhetô viselkedéses válaszok formájában (pl. támadj-vagy-menekülj viselkedésreakció, lefagyás). Mindkettô automatikusan jelenik meg, és nem feltételük a félelem tudatos megtapasztalása (LeDoux, 2013, 2014). A félelem átélésének két legfőbb jellemzóje viszont (1) a félelem élményének kellemetlensége (negatív valencia), valamint (2) az érzelem beazonosítása, azaz annak megállapítása, ha valaki félelmet él át (lásd 2. ábra). 


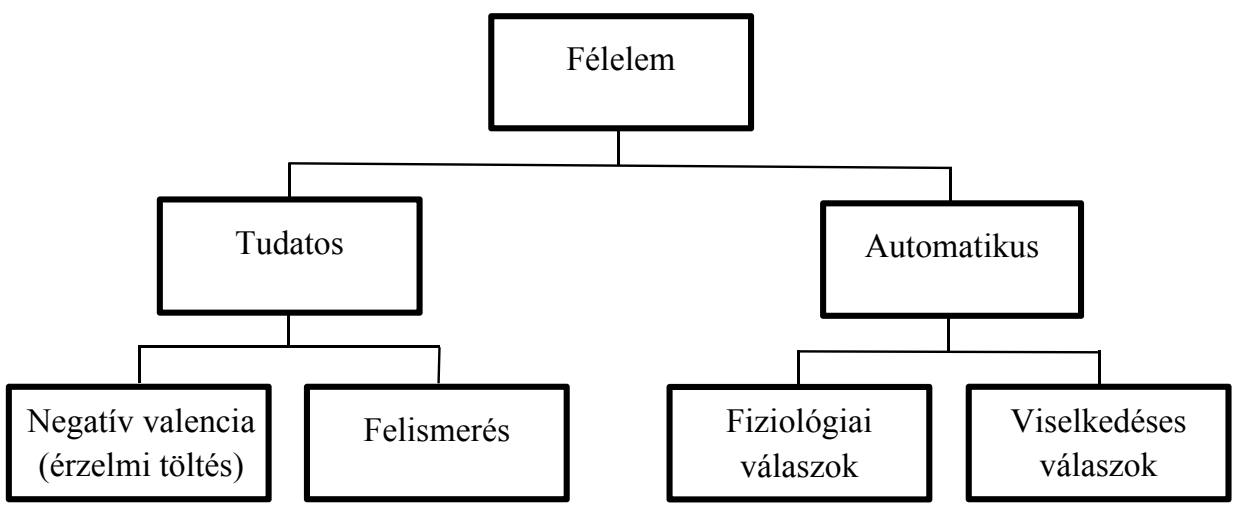

2. ábra. A félelem összetevőinek modellje

Forrás: Hoppenbrouwers és mtsai, 2016, 575.

\section{CÉLKITÚZZÉSEK}

Az ismertetett elméletek tükrében fontos kérdéssé válik tehát, hogy a pszichopátiás vonásokra jellemzó érzelmi deficit (1) csak bizonyos érzelmek és (2) modalitások esetében nyilvánul meg, vagy pervazív zavarról lehet inkább szó, illetve (3) az érzelmi feldolgozásnak milyen területein, szintjein jelenik meg a zavar. Ha abból a megközelítésbôl indulunk ki, miszerint magas CU vonások mellett a szemekre, a tekintetre adott figyelmi válasz sérült (Dadds és mtsai, 2006, 2008, 2011), akkor lényegében csak az érzelmi arckifejezések esetében számíthatunk feldolgozási deficitre, ami akár több érzelmet is érinthet. Más elméletek alapján (Bird, Viding, 2014; Blair, 1995, 2005; Lykken, 1957) viszont azt feltételezhetjük, hogy érzelmi zavar leginkább az averzív, distresszkeltô jelzésekre (szomorúság, félelem, fájdalom) vonatkozik, ami modalitástól függetlenül, vagyis hangok, szavak, képek (és nemcsak arcképek, hanem pl. negatív érzelmet tükrözó jelenetek, testtartások) esetén is megmutatkozik, illetve a figyelemelôttes, nem tudatos feldolgozás szintjén is megjelenik (tehát nem magyarázható pusztán a magasabb szintû, „top-down” figyelemi folyamatok zavarával; Newman, Lorenz, 2003 - lásd 1. táblázat).

Az alábbiakban bemutatásra kerülô vizsgálatok jelentôs eltérést mutatnak abban, hogy az érzelmi válasz mely területeit, illetve milyen módszerekkel mérik. Ahhoz, hogy a fentebb ismertetett, egymással versengó elméleteket értékelni tudjuk és a pszichopátiás vonásokkal társuló érzelmi deficitet mélyebben megértsük, fontos látnunk, hogy a kutatások pontosan milyen paradigmákkal, feladattal dolgoztak, illetve az érzelmi feldolgozásnak mely területeivel találtak összefüggéseket. Bár a kutatások többsége az összesített pszichopátiás vonásokat vagy annak központi jegyeit, azaz a CU vonásokat mérik, külön kiemeljük, ha a nárcizmus vagy az impulzivitás szerepét is vizsgálták (lásd Mellékletek 2. táblázat). Számos tanulmány koncentrál továbbá kifejezetten a viselkedési zavarok és az érzelmi feldolgozás kapcsolatára (pl. Áspán, Vida, Gádoros 
1. táblázat. A pszichopátiában megfigyelhetô érzelmi zavar magyarázó modelljei

\begin{tabular}{l|l|l|l}
\hline Elmélet & Az érzelmi feldolgozás \\
érintett területe, szintje & $\begin{array}{l}\text { Specifikus / } \\
\text { generalizált } \\
\text { érzelmi zavar }\end{array}$ & Érintett modalitás \\
\hline $\begin{array}{l}\text { Alacsony félelem modell } \\
\text { (Lykken, 1957; Patrick, } \\
1994)\end{array}$ & $\begin{array}{l}\text { Tudatos és automatikus } \\
\text { érzelmi feldolgozás }\end{array}$ & $\begin{array}{l}\text { Specifikus } \\
\text { (averzív, } \\
\text { büntetéssel } \\
\text { kapcsolatos } \\
\text { jelzések) }\end{array}$ & Pervazív \\
\hline $\begin{array}{l}\text { Integrált érzelmi } \\
\text { rendszerek modell } \\
\text { (Blair, 2005) }\end{array}$ & $\begin{array}{l}\text { Tudatos és automatikus } \\
\text { érzelmi feldolgozás }\end{array}$ & $\begin{array}{l}\text { Specifikus } \\
\text { (distressz jelzések) }\end{array}$ & Pervazív \\
\hline $\begin{array}{l}\text { Empátia } \\
\text { onmagunk-mások } \\
\text { modellje } \\
\text { (Bird, Viding, 2014) }\end{array}$ & $\begin{array}{l}\text { Tudatos és automatikus } \\
\text { érzelmi feldolgozás }\end{array}$ & $\begin{array}{l}\text { Specifikus } \\
\text { (distressz jelzések) }\end{array}$ & Pervazív \\
\hline $\begin{array}{l}\text { Válaszmoduláció elmélet } \\
\text { (Newman, Lorenz, 2003) }\end{array}$ & $\begin{array}{l}\text { Magasabb szintú, tudatos } \\
\text { figyelmi folyamatok }\end{array}$ & $\begin{array}{l}\text { Figyelmi fókusztól } \\
\text { függ }\end{array}$ & $\begin{array}{l}\text { Célok } \\
\text { szempontjából } \\
\text { irreleváns ingerek }\end{array}$ \\
\hline $\begin{array}{l}\text { Tekintetre adott figyelmi } \\
\text { válasz zavara } \\
\text { (Dadds és mtsai, } \\
\text { 2006, 2008) }\end{array}$ & $\begin{array}{l}\text { Automatikus figyelmi } \\
\text { folyamatok }\end{array}$ & Generalizált & $\begin{array}{l}\text { Vizuális } \\
\text { (szemek, tekintet) }\end{array}$ \\
\hline
\end{tabular}

Megjegyzés: Az elsô három modell esetében az érzelmi feldolgozás tudatos szintje az averzív érzelmek átélésére, tudatos megtapasztalására vonatkozik, míg az automatikus feldolgozás a figyelemelốttes folyamatokat, az érzelmi ingerekre adott automatikus válaszokat érinti (lásd 2. ábra, Hoppenbrouwers és mtsai, 2016).

és Halász, 2013; Halász, Áspán, Bozsik, Gádoros és Inántsy-Pap, 2013; Passamonti és mtsai, 2010), jelen összefoglaló viszont csak azokat a kutatásokat ismerteteti, melyek a pszichopátiás vonásokat (is) mérték.

\section{AZ ÉRZELEMI FELDOLGOZÁS VIZSGÁLATI MÓDSZEREI}

\section{Figyelmi torzítás az érzelmi ingerekre}

Az érzelmi feldolgozás vizsgálatának az egyik legelterjedtebb módszere az érzelemkeltố ingerekre adott válasz gyorsaságának (reakcióidô), illetve pontosságának mérése a semleges ingerekhez viszonyítva, ahol a hosszabb reakcióidó az érzelmi feldolgozás zavarát tükrözi. Erre a módszerre épül egy figyelmi paradigma, az ún. figyelmi torzítás próba (dot-probe) is, mely az érzelmi ingerekre adott viselkedéses válasz népszerú mérôeszköze (különösen a szorongással kapcsolatos kutatásokban; összefoglalóért lásd: Mogg és Bradley, 1998).

A feladat több próbából épül fel, amelyek kezdetén egy ún. fixációs kereszt látható (általában 500 ms ideig), ami a képernyô közepére tereli a figyelmet. Ezt követóen 


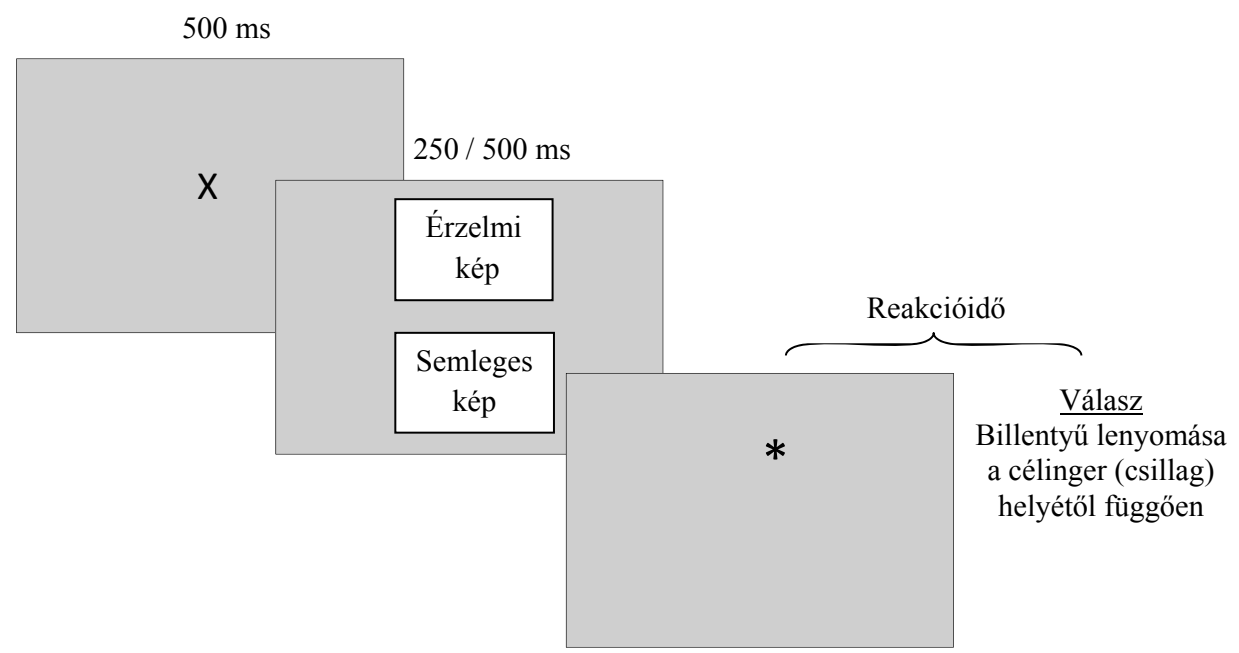

3. ábra. A figyelmi torzítás próba (dot-probe) felépítése

egyszerre két kép (egy semleges és egy érzelmi tartalmú inger) villan fel a képernyó két oldalán. Ezek a képek csak rövid ideig láthatóak (pl. 250 vagy 500 ms ideig), majd egy célinger (pl. egy csillag) jelenik meg az egyik képnek a helyén (lásd 3. ábra). A vizsgálati személy feladata pedig, hogy minél gyorsabban jelezze a célinger helyét a megfelelố billentyú lenyomásával. A teszt lényegében arra a feltételezésre épül, hogy a célingerre adott reakcióidô rövidebb lesz, ha a résztvevô figyelme már eleve oda összpontosul. Vagyis ha a válaszidô azokban a próbákban lesz rövidebb, amikor a célinger az érzelmi tartalmú kép helyén jelenik meg (szemben azokkal, amikor a semleges inger helyén), akkor az érzelmi képek javára mutatott figyelmi torzításról beszélhetünk. Ellenkezô esetben viszont az érzelmi információk figyelmi elkerülésérôl lehet inkább szó.

Úgy tûnik, hogy ebben a feladatban a magas CU vonásokat és viselkedési problémákat is mutató serdüló fiúk lassabban reagálnak a negatív érzelmi ingerekre (distresszkeltô képek vagy szavak) a semleges ingerekhez viszonyítva (Kimonis, Frick, Cauffman, Goldweber és Skeem, 2012; Kimonis, Frick, Muñoz és Aucoin, 2008; Kimonis, Graham és Cauffman, 2017; Loney, Frick, Clements, Ellis és Kerlin, 2003; Szabó, Halász, Morgan, Demetrovics és Kökönyei, in press). Ezt az összefüggést nemcsak bûnelkövetô fiúk, hanem normál, egészséges gyerekek körében is sikerült igazolni (a nem kontrollálása mellett) (Frick és mtsai, 2003; Kimonis, Frick, Fazekas és Loney, 2006). Emellett különösen alacsony szintû szorongás mellett kifejezett (Kimonis és mtsai, 2012), illetve már óvodáskorban, 3-5 éves gyerekek körében is kimutatható (Kimonis és mtsai, 2016).

Ezzel szemben a CU vonásokkal nem rendelkezô, viselkedési problémás fiatalok inkább fokozott figyelmi választ mutatnak a negatív érzelmi ingerekre (Frick és mtsai, 2003; Kimonis és mtsai, 2006, 2008, 2017; Loney és mtsai, 2003; Szabó és mtsai, in press), illetve a pszichopátia másik két dimenziója, azaz a nárcizmus és az impulzivitás 
ugyancsak megnövekedett figyelmi orientációval társul a distresszt kifejezó jelzésekre (bûnelkövetô fiúk mintájában) (Loney és mtsai, 2003; Muñoz, Kimonis, Frick és Aucoin, 2013).

Fontos megemlíteni ugyanakkor, hogy a fenti, érzelmi képekkel dolgozó figyelmi torzítás vizsgálatok ingeranyaga a Nemzetközi Affektív Képrendszer (International Affective Picture System; IAPS; Lang, Bradley és Cuthbert, 1997) adatbázisából származik. Ezek a fotók pozitív (pl. labdázó delfinek, nevetô csecsemô) és negatív (pl. támadó kutya, síró gyerek) érzelmek kiváltására alkalmas jeleneteket ábrázolnak, a semleges tartalmú képeken viszont legfóképpen mindennapi tárgyak (pl. fésú, szék) láthatóak. A feladat egyik hátránya, hogy a negatív, distresszkeltó képek jóval nagyobb arányban ábrázolnak embereket, mint a pozitív és a semleges tartalmú képek, vagyis lehetséges, hogy az eredmények a képeken látható emberek látványához, nem pedig a képek negatív érzelmi tartalmához köthetôk (Colden, Bruder és Manstead, 2008; Kimonis és mtsai, 2008; Wiens, Sand és Olofsson, 2011).

Azt is lényeges kiemelni, hogy az eddigi vizsgálatokban más-más ingerbemutatási idôvel dolgoztak. A figyelmi torzítás próbákban ugyanis $250 \mathrm{~ms}$ (Kimonis és mtsai, 2012; Kimonis, Frick, Muñoz és Aucoin, 2007; Kimonis és mtsai, 2008, 2017; Szabó és mtsai, in press), illetve 500 ms (Kimonis és mtsai, 2006, 2008) vetítési idôt is alkalmaztak az érzelmi képek bemutatására. Ezek alapján úgy túnik, hogy (a szorongással kapcsolatos vizsgálatokhoz hasonlóan) a rövidebb ingerbemutatás vezet robosztusabb eredményekhez, legalábbis a magas kockázatú, búnelkövetô fiúk mintájában (Bradley, Mogg, Falla és Hamilton, 1998; Kimonis és mtsai, 2008). Rövidebb prezentálási idő mellett a tudatos felismerés jobban kikerülhetô, vagyis ez a módszer leginkább a distresszkeltô vizuális ingerek automatikus feldolgozásának zavarát, illetve az erre vonatkozó elméleteket igazolja (alacsony félelem modell, integrált érzelmi rendszerek modell, empátia önmagunk-mások modellje).

A figyelmi torzítás próba ugyanakkor nem alkalmas azon figyelmi folyamatok mélyebb szintû feltérképezésére, melyek a torzításra is közvetlen hatással lehetnek. Így például nem alkalmas arra, hogy a distresszkeltố ingerekre adott automatikus figyelmi orientációt vagy a distresszkeltố ingerek többé-kevésbé akaratlagos elkerülését mérje. Továbbá ez a paradigma nem ad információt a figyelem másik ingerre való átvitelérôl (Cisler és Koster, 2010). Újabb pszichometriai kutatások szerint ráadásul a reakcióidô-mutatók gyenge ismételt méréses (teszt-reteszt), illetve felezéses (split-half) megbízhatósággal rendelkeznek, így érdemes más, például a szemkövetéses (eye tracking) módszerek mutatóira is alapozni a figyelmi torzítás vizsgálataiban (Brown és mtsai, 2014; Price és mtsai, 2015).

\section{Szubjektív érzelmi reaktivitás}

Az IAPS képeket gyakran alkalmazzák a kiváltott élmény érzelmi töltetének (valencia) és intenzitásának (arousal) mérésére is a gyermekkori pszichopátiás vonások vonatkozásában. Ehhez az ún. Self-Assessment Manikin (SAM; Bradley és Lang, 1994; magyar nyelvú adaptációja: Saját-érzés Mutató; SAMU; Deák, 2011) nemverbális értékelési eljárást használják, ahol a résztvevook a képek megtekintését követôen emberi 

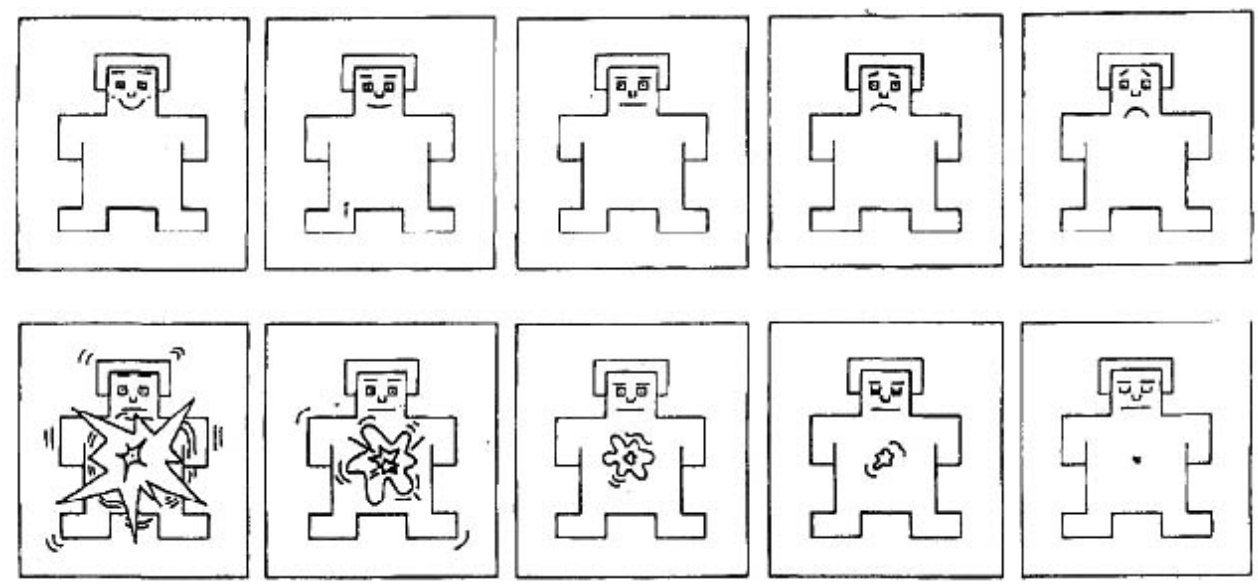

4. ábra. SAMU-skálák a valencia (felsố sor) és az arousal (alsó sor) mérésére.

Forrás: Bradley és Lang, 1994, 51.

figurák által meghatározott affektív dimenziók mentén értékelik a szubjektív érzelmi élményeiket. A valencia esetében a skála egyik végén a SAMU-figura mosolygós arcot mutat, a másikon viszont boldogtalan az arckifejezése. Az intenzitás (arousal) két végpontja pedig izgatottságot és nyugodt érzelmi állapotot ábrázol (lásd 4. ábra). A válaszok kilencfokú Likert-skálának megfelelően rögzíthetôk az öt figura, illetve a figurák közti üres mezôk jelölésével.

Ezen vizsgálatok eredményei szerint az összesített pszichopátiás vonások (Sharp, Van Goozen és Goodyer, 2006), valamint a CU vonások (Masi és mtsai, 2014; Michonski és Sharp, 2010) a distresszkeltô képek pozitívabb értékelésével társulnak, illetve fordított kapcsolatot mutatnak azok érzelmi intenzitásával a diszruptív viselkedési zavarral diagnosztizált és az egészséges fiatalok körében egyaránt. Úgy tûnik tehát, hogy magas CU vonások esetén csökkent érzelmi reaktivitás figyelhetố meg a kellemetlen, intenzív érzelmeket kifejezô képekre (a nem és a kor kontrollálása mellett).

A fenti vizsgálati módszer jól alkalmazható az érzelmi feldolgozással kapcsolatos szubjektív érzések megragadására, az eredmények pedig azokat a megközelítéseket támogatják, amelyek magas pszichopátiás vonások mellett a distressz átélésének, megtapasztalásának zavarát hangsúlyozzák (alacsony félelem modell, integrált érzelmi rendszerek modell, empátia önmagunk-mások modellje). Mivel az érzéseket nem kell megfogalmazni, verbalizálni, a kognitív folyamatok is jobban kikerülhetôk (akárcsak a pszichofiziológiai mérések alkalmazása esetén, lásd Pszichofiziológiai reakciók alfejezet). Hátránya viszont, hogy az egymással párhuzamosan fellépó érzelmek kifejezésére, differenciálására nem alkalmas ez a módszer. Egy újabb vizsgálat eredményei szerint pedig az IAPS képek már nem váltanak ki olyan erôs érzelmi választ (arousal növekedést), mint amikor kidolgozták óket (Betella és Verschure, 2016). Úgy túnik, csökkent érzékenység (deszenzitizáció) figyelhetô meg az averzív érzelmi ingerekre, mely a tanulmány szerint leginkább a médiának való túlzott kitettséggel magyarázható. 
Az eddigi vizsgálatoktól ugyanakkor jól elkülöníthetôek az érzelmi felismerésre koncentráló kutatások, melyek leginkább az ún. univerzális vagy alapérzelmeket tükrözô arckifejezések (boldogság, harag, félelem, meglepódés, szomorúság, undor; Ekman, 1992) felismerési pontosságát mérik a fiatalkori pszichopátiás vonásokkal összefüggésben. Az érzelmi arcokra koncentráló vizsgálatok lényegében két csoportra oszthatók aszerint, hogy tudatos vagy automatikus módon mérik az érzelmi kifejezések feldolgozását. Az előbbi esetben a vizsgálati személyeknek az arcokon látott érzelmeket kell beazonosítaniuk, az automatikus feldolgozást mérô feladatokban viszont nem az arcok érzelmi tartalmát, hanem ettôl független információkat, például az arcok nemét, korát vagy helyét kell jelezniük.

\section{Érzelmi arckifejezések tudatos feldolgozása}

A témában végzett legkorábbi vizsgálatok az Ekman és Friesen (1976) által kidolgozott ingeranyagot használták, de különbséget mutatnak abban, hogy milyen módszereket, elrendezést alkalmaztak az arckifejezések prezentálására. Ezek a vizsgálatok egyfelôl eltérnek abban, hogy a fiataloknak inkább természetes érzelmeket tükrözó (Blair, Colledge, Murray és Mitchell, 2001; Kimonis és mtsai, 2016; Muñoz, 2009; Stevens, Charman és Blair, 2001) vagy olyan grafikusan átalakított arcképeket kell megnevezniük, ahol a különbözô alapérzelmeket egymással maszkolták, azaz morfolták az ingeranyagot (Blair és Coles, 2000; Fairchild, Stobbe, van Goozen, Calder és Goodyer, 2010; Fairchild, van Goozen, Calder, Stollery és Goodyer, 2009). Az utóbbi esetben, az arcokkal kapcsolatos döntések megnehezítésére, az egyes alapérzelmeket az ún. érzelmi hexagonnak megfelelố szomszédjukkal maszkolták. Tehát azokat az érzelmeket „keverték össze” egymással meghatározott arányokban (90\%-10\%, 70\%-30\%, $50 \%-50 \%, 30 \%-70 \%, 10 \%-90 \%$ ), amelyeket a leggyakrabban összetévesztenek egymással az emberek (ezek az érzelempárok a következôk: boldogság-meglepôdés, meglepoodés-félelem, félelem-szomorúság, szomorúság-undor, undor-düh, düh-boldogság; Ekman és Friesen, 1976).

Ezen vizsgálatok szerint az összesített pszichopátiás vonások és a CU vonások jelenléte a félelmet kifejezô arcok felismerési zavarával társul egészséges fiatalok (Blair és Coles, 2000), illetve komoly viselkedési problémákat mutató fiúk körében egyaránt (Blair és mtsai, 2001; Fairchild és mtsai, 2009; Muñoz, 2009; Stevens és mtsai, 2001). Többet hibáznak a félelmi arcok megnevezésekor, ez az összefüggés pedig a viselkedési problémák, a kor, az IQ, illetve (az egészséges minta esetében) a nem kontrollálása mellett is megmaradt.

Egyes vizsgálatok azonban nemcsak a félelem, hanem a szomorúság esetében is (Blair és Coles, 2000; Fairchild és mtsai, 2009; Kimonis és mtsai, 2016; Stevens és mtsai, 2001), vagy egyedül a szomorúság felismerésében találtak zavart (Fairchild és mtsai, 2010; Woodworth, Waschbusch, 2008). Az utóbbi két kutatásban ugyanakkor viselkedési problémákkal küzdô lányokat (Fairchild és mtsai, 2010), illetve figyelemhiányos hiperaktivitás-zavarral diagnosztizált fiatalokat vizsgáltak (Woodworth és Waschbusch, 2008). Egy-egy kutatásban pedig a pszichopátiás vonásokat mutató fiúk a félelem és a 
szomorúság mellett más alapérzelmek tekintetében is alulteljesítettek (harag: Muñoz, 2009; meglepôdés: Fairchild és mtsai, 2009).

Fontos számításba venni azonban, hogy a félelem az egyik legnehezebben felismerhetô érzelem (Ekman és Friesen, 1976; Kohler és mtsai, 2004; Montagne, Kessels, De Haan és Perrett, 2007), így a fenti eredmények akár a feladat nehézségéból is fakadhatnak. Ezzel szemben viszont a szomorúság egyike a legkönnyebben beazonosítható érzelmeknek, és ebben ugyancsak rosszul teljesítenek a magas pszichopátiás vonásokat mutató fiatalok. Kritikaként említhetô továbbá, hogy az Ekman és Friesen (1976) által összeállított képsorozat - bár széles körben validált és standardizált ingeranyag - több mint 40 éve készült, sokak szerint inkább mesterséges és eltúlzott érzelmeket közvetít, illetve a dinamikus vagy a háromdimenziós képekhez képest alacsony az ökológiai validitásuk (nehezen általánosíthatók a hétköznapi körülményekre) (Alves, 2013). Tény ugyanakkor, hogy alig van olyan vizsgálat, amely a 100\%-os intenzitású (prototipikus) érzelmi képeket alkalmazná (a fent bemutatott kutatások közül egyedül az iskoláskorú gyerekeknél fiatalabb korosztály esetében használták; Kimonis és mtsai, 2016).

Újabb kutatásokban azonban már rövidebb videókat, dinamikusan változó arckifejezéseket is alkalmaztak viselkedési problémákat mutató fiúk (Schwenck és mtsai, 2012; Wolf és Centifanti, 2014), illetve lányok körében egyaránt (Schwenck és mtsai, 2014). Egy vizsgálatban pedig a fájdalom kifejezése is szerepelt az érzelmi ingerek között (Wolf és Centifanti, 2014). Az eredmények szerint a CU vonások szintje a negatív érzelmi ingerek közül egyedül a fájdalom megnevezésével mutatott fordított összefüggést (a szomorúsággal és a félelemmel nem). Lányok esetében pedig a magas CU vonásokat mutató csoport még jobban is teljesített a félelmi ingerek feldolgozásában a kontrollcsoporthoz, illetve az alacsony CU vonásokat, de magas viselkedési problémákat mutató mintához képest is.

Hátrányként említhetô meg, hogy ezekben a vizsgálatokban is kényszerválasztásos elrendezést alkalmaztak az érzelmek megnevezése során, amely olyan válaszokat hívhat elô, amire a vizsgálati személy magától talán nem is gondolna (Cassels és Birch, 2014). Ez különösen problémás lehet magas CU vonások esetén, hiszen pont ezek a fiatalok azok, akik különbözô kompenzáló, kognitív stratégiákat alkalmazhatnak a feladat megoldása alatt (az érzelmi zavaruk miatt).

\section{Érzelmi arckifejezések automatikus feldolgozása}

A fenti módszerek inkább a tudatos figyelmi folyamatokat ragadják meg, más vizsgálatokban viszont olyan feladatokat alkalmaztak magas kockázatú, viselkedési problémákat mutató fiúk körében, melyek a figyelemelôttes, automatikus feldolgozásra koncentráltak (Hodsoll, Lavie és Viding, 2014; Sylvers, Brennan és Lilienfeld, 2011). Sylvers és munkatársai (2011) kutatásában egyszerre kétféle ingert mutattak a résztvevôknek: egy statikus érzelmi arcot láttak az egyik szemükkel (boldogság, félelem, undor vagy semleges arc), a másikkal viszont egy folyamatosan változó vizuális ingert, amely hosszabb-rövid időre elnyomja az érzelmi arcok tudatosulását (continuous flash suppression; CFS; Tsuchiya és Koch, 2004). A feladat során pedig azt kellett jelezniük, hogy a képernyố melyik sarkában jelenik meg érzelmi arc. Ebben a vizsgálatban egyedül a CU vonások szintje mutatott fordított kapcsolatot a félelmet és az undort 
kifejezô arckifejezések feldolgozásával. A nárcizmus és az impulzivitás dimenziókkal viszont semmilyen összefüggést nem találtak.

Hodsoll, Lavie és Viding (2014) pedig egy téri-vizuális keresésre koncentráló feladatot alkalmazott, ahol egy célinger (egy férfi arc) irányát kellett meghatározni (ami balra vagy jobbra dôlt). A vizsgálati személyek mindig három arckifejezést láttak a képernyoón (két nôi és egy férfi arc), amelybôl az egyik valamilyen érzelmet tükrözött (félelem, harag vagy boldogság), a másik kettô pedig semleges arc volt. Eredményeik szerint a magas CU vonásokkal, illetve viselkedési problémákkal jellemezhetô fiúk figyelmét nem befolyásolta az arcok érzelmi töltete, miközben az alacsony CU vonásokat, de magas viselkedési problémákat mutatók teljesítményét megzavarta a feladatirreleváns, elterelố ingerek érzelmi tartalma.

Bár mindkét vizsgálatban másra vonatkozott az instrukció, valójában az érzelmi ingerekre adott válaszok gyorsaságát (reakcióidő) mérték a semleges arcokhoz viszonyítva, ami az automatikus érzelmi felismerés vizsgálatának eszköze. Az így kapott eredmények tehát ellentmondanak annak a megközelítésnek, miszerint pszichopátiában a magasabb szintú, tudatos figyelmi folyamatok deficitjérôl lehet inkább szó (Newman és Lorenz, 2003). Ahogy korábban már bemutatásra került, a figyelmi torzítás próba is erre a módszerre épül (csak IAPS képeket alkalmazva), illetve a funkcionális mágneses rezonancia (fMRI) kutatásokban használják még elterjedten, ahol az érzelmi arcokra mutatott agyi aktivitást mérik a pszichopátiás vonásokkal összefüggésben (lásd Az érzelmi zavar neurális vonatkozásai alfejezet).

Az eddig ismertetett, az érzelmi arcok felismerési zavarát bizonyító eredmények tehát továbbra is azokat a modelleket támogatják, melyek az érzelmi feldolgozás tudatos és automatikus összetevôjének zavarát hangsúlyozzák. Ezek a vizsgálatok ugyanakkor nem mérték az érzelmi arcok tekintetére vonatkozó figyelmi válaszokat.

\section{Érzelmi tekintet}

Egyes eredmények szerint az érzelmi arcok felismerési zavara attól is függ, hogy az emberi arcnak milyen részeire irányul a figyelem (Dadds és mtsai, 2006, 2008). Ezeket a vizsgálatokat normál, egészséges fiúk körében végezték el. Mindig az arcokon látott érzelmeket kellett megnevezni, de a vizsgálat második, illetve harmadik szakaszában az arcok szemére, majd szájára kellett figyelni. A korábbi vizsgálatokkal összhangban a magas CU vonásokat mutató fiatalok a félelem felismerésében többet hibáztak, mint az alacsony CU vonásokkal jellemezhetố társaik, ez a különbség azonban eltúnt, amikor a szemekre fókuszáltak, és újra megjelent, amikor az arcok szájára.

Úgy tûnik, hogy a tekintetre irányított figyelem fokozhatja az érzelmi reaktivitást, a CU vonásokat mutató fiatalok azonban kevesebb figyelmet fordítanak az arcok szem régiójára (rövidebb és kevesebb fixáció) a kontrollcsoporthoz képest, amit a szemmozgás monitorozásával (eye tracking) mutattak ki a szerzók (Dadds és mtsai, 2008). Következtéseik szerint a magas CU vonásokkal rendelkezó fiatalok képtelenek az emberi arc kritikus érzelmi jegyeit megfelelően feldolgozni. A félelmet kifejezó arcok felismerési zavara helyett tehát a tekintetre irányuló figyelem deficitjét emelik ki.

Azonban az eddigi vizsgálatoktól eltérô, a kutatócsoport által kifejlesztett ingeranyagot használtak az érzelmi feldolgozás mérésére (University of New South Wales 
[UNSW] Facial Emotion Task; Dadds, Hawes és Merz, 2004), illetve a CU vonások vizsgálatára is saját mérốeszközt dolgoztak ki (Dadds, Fraser, Frost és Hawes, 2005), ami megnehezíti az eredmények összehasonlítását más kutatásokkal. Az összefüggést továbbá csak egészséges fiúknál vizsgálták, és alacsony mintaelemszámmal is dolgoztak, így szükség lenne arra, hogy a kapott összefüggéseket további kutatások is megerôsítsék.

\section{Érzelmet kifejezô hangok és testtartások}

Az érzelemfelismerés zavara ugyanakkor más típusú, más modalitású ingerek esetében is megmutatkozik, nemcsak a félelmet kifejezô arcok esetében. Vokális jelzések, hangok felismerését vizsgálva ugyanis a magas pszichopátiás vonásokat mutató csoport rosszabbul teljesített a szomorúságot (Stevens és mtsai, 2001) és a félelmet kifejezô ingerek felismerésében (Blair, Budhani, Colledge és Scott, 2005), mint a kontrollcsoport. Mindkét kutatásban érzelmi és viselkedési problémákat mutató serdüló fiúkat vizsgáltak, ugyanakkor más feladattal, ingeranyaggal dolgoztak (pl. semleges szavak vs. mondatok, felnôttek vs. gyerekek hangján). Fontos megemlíteni továbbá, hogy a félelemmel kapcsolatos eredmény nem magyarázható a feladat nehézségével. Bár ebben a feladatban általában gyengébben teljesítenek a résztvevôk az érzelmi arcokhoz képest, úgy tünik, a félelem könnyebben felismerhetô, ha hanggal van kifejezve (Blair, Budhani, Colledge és Scott, 2005; Scott és mtsai, 1997).

Bizonyított továbbá, hogy magas szintú CU vonások esetén a félelmet (Muñoz, 2009) és a haragot kifejezô testtartások (Wolf és Centifanti, 2014) felismerése is nehézséget okoz viselkedési problémákat mutató fiúk körében. Az elsố vizsgálatban ugyanakkor statikus képeket használtak, ahol az adott érzelmekre csak az (álló) testhelyzetekból lehetett következtetni (Muñoz, 2009), miközben a második kutatásban olyan videókat mutattak, ahol a legfontosabb testrészeket (pl. kéz, láb, fej) fényfoltokkal ábrázolták (melyek mozgásban egy mozgó emberi test látványát keltik). Úgy tûnik tehát, hogy a statikus vagy dinamikusan változó testhelyzetek felismerésének vizsgálata - az érzelmi arcokhoz hasonlóan - eltérő eredményekhez vezethet. Mindazonáltal megállapítható, hogy a negatív érzelmi tartalmú, averzív jelzések felismerési zavara az auditoros és a testhelyzetet ábrázoló vizuális ingerekre is kiterjeszthetô, vagyis pervazív zavart tükröz, és túlmutat azon a megközelítésen (Dadds és mtsai, 2011), mely a tekintetre irányuló figyelmi válasz deficitjét emeli ki.

\section{Az érzelmi zavar neurális vonatkozásai}

Az eddig ismertetett, viselkedéses válaszokra koncentráló kutatások mellett a képalkotó vizsgálatok is alátámasztják, hogy a pszichopátiás vonásokat mutató gyerekek és serdülók másképp dolgozzák fel a félelemmel kapcsolatos jelzéseket. Több fMRI vizsgálat is igazolja, hogy ezeknél a fiataloknál a félelmi arcok megfigyelése alatt az amygdala csökkent aktivitása figyelhetố meg, nemcsak a kontrollcsoportokhoz viszonyítva (Jones, Laurens, Herba, Barker és Viding, 2009; Klapwijk és mtsai, 2016; Marsh és mtsai, 2008; Viding és mtsai, 2012; White és mtsai, 2012), hanem a magas viselkedési 
problémákat, de alacsony CU vonásokat mutató fiatalokhoz képest is (Viding és mtsai, 2012). Egy vizsgálatban pedig gyengébb kapcsolatot (funkcionális konnektivitást) találtak az amygdala és a ventromediális prefrontális kéreg között a CU vonások jelenlétében (Marsh és mtsai, 2008).

Az érzelmi arcok neurális feldolgozását többségében olyan feladatokkal mérték, ahol az arckifejezések nemét kellett jelezni (automatikus érzelemfelismerés) (Fairchild és mtsai, 2014; Jones és mtsai, 2009; Marsh és mtsai, 2008), egy vizsgálatban pedig rövid ideig látható $(17 \mathrm{~ms})$ és semleges arcokkal maszkolt félelmi arcokkal dolgoztak (passzív megfigyelés) a figyelemelôttes feldolgozás megragadására (Viding és mtsai, 2012). White és munkatársai (2012) ugyanakkor a figyelmi terhelés szerepét is vizsgálták: feladatukban az érzelmi arcok két egyenes között helyezkedtek el, ezekrôl kellett eldönteni, hogy párhuzamosak-e vagy sem. Eredményeik szerint az amygdala aktivitása fordított kapcsolatot mutatott a CU vonások szintjével (a nárcizmussal és az impulzivitással nem) a félelmi arcok feldolgozása alatt, de csak alacsony figyelmi terhelés mellett, ami az érzelmi deficit elsôdleges szerepére hívja fel a figyelmet a top-down figyelmi folyamatok zavara helyett. Egy másik fMRI vizsgálatban pedig egyedül az érzelmi rezonancia mérése alatt találtak összefüggést az amygdalaaktivitás és a CU vonások között (Klapwijk és mtsai, 2016). Ekkor a résztvevőknek az arckifejezések megfigyelése alatt a saját érzelmi válaszaikat kellett értékelniük (szemben azzal, amikor az arcokon látott érzelmet kellett jelezniük).

Fontos kiemelni azonban, hogy ezek az fMRI vizsgálatok csak félelmet és haragot tükrözô, illetve semleges arckifejezéseket használtak, illetve viselkedési problémákat mutató fiúkra koncentráltak (Jones és mtsai, 2009; Klapwijk és mtsai, 2016; Viding és mtsai, 2012; White és mtsai, 2012). Bár egy vizsgálatban szomorúságot kifejezô arcokat is alkalmaztak (a félelem helyett) serdülôkorú lányok körében (Fairchild és mtsai, 2014), nem találtak csökkent aktivitást az amygdala területén a CU vonásokkal összefüggésben. Ezzel ellentétben a fusiform gyrus területén - amely az érzelmi arcok feldolgozásában jelentôs - viszont volt kapcsolat.

A magas CU vonásokat mutató fiatalok ugyanakkor mások fájdalmára, szenvedésére is eltérô agyi aktivitást mutatnak (Lockwood és mtsai, 2013; Marsh és mtsai, 2013). Mindezt olyan képek segítségével vizsgálták, amelyeken különbözô testrészek láthatóak fájdalmas (pl. valaki a kezére csukja az ajtót), illetve nem fájdalmas helyzetekben ábrázolva (pl. ugyanaz a kéz az ajtó kilincsét fogja) (Jackson, Meltzoff és Decety, 2005). A vizsgálatok viselkedési problémákat mutató fiatalokra koncentráltak, akiknek vagy azt kellett jelezniük, hogy kezet vagy lábat látnak a képernyőn (Lockwood és mtsai, 2013), vagy azt kellett elképzelniük, hogy velük vagy mással történik a fájdalmas jelenet (Marsh és mtsai, 2013). Az eredmények szerint a CU vonások szintje fordított kapcsolatot mutatott az anterior insula és az anterior cinguláris kéreg aktivitásával, mely területek a fájdalom miatt érzett empátiával is összefüggésbe hozhatók (Lamm, Decety és Singer, 2011). Mindemellett az amygdala csökkent aktivitása is megfigyelhetô volt, de csak akkor, ha mások helyébe kellett képzelniük magukat. Úgy túnik tehát, hogy a fiatalkori pszichopátiás vonásokra jellemzó érzelmi sekélyesség a neurális válaszok szintjén is megmutatkozik. Továbbá nemcsak a distresszt kifejezó arcok automatikus feldolgozása érintett, hanem más (fájdalmas jelenetet ábrázoló) vizuális ingerek alkalmazása esetén is megfigyelhetô. 


\section{Pszichofiziológiai reakciók}

A kutatások másik fontos csoportját végül azok a vizsgálatok alkotják, melyek az érzelmi deficit jelenlétét az automatikus testi reakciókban, a pszichofiziológiai válaszokban mutatták ki. Az egyik legkorábbi vizsgáltban elektrodermális aktivitást mértek a negatív érzelmi tartalmú IAPS képek feldolgozása alatt, és csökkent bôrvezetéses választ találtak a magas pszichopátiás vonásokat mutató, serdülókorú fiúk körében a kontrollcsoporthoz viszonyítva (Blair, 1999). Újabb vizsgálatokban pedig félelmet (Anastassiou-Hadjicharalambous és Warden, 2008), illetve szomorúságot, haragot és boldogságot kiváltó filmjeleneteket alkalmaztak (de Wied, van Boxtel, Matthys és Meeus, 2012), miközben a szívfrekvencia-változást monitorozták. Az eredmények szerint azok a fiatalok, akik viselkedési problémákkal és CU vonásokkal egyaránt jellemezhetôk, a félelmet és szomorúságot keltô filmjelenet nézése közben kisebb mértékú szívfrekvencia-változást mutatnak, mint a magas viselkedési problémákkal, de alacsony CU vonásokkal rendelkezôk. A distressz jelzések feldolgozása alatt tehát csökkent autonóm válasz, hipoarousal jellemzi ezeket a fiatalokat.

Az érzelmi ingerekre adott válaszkészséget ugyanakkor az egyik vizsgálatban az arcizmok aktivitásával, vagyis elektromiográf segítségével is mérték, és a magas CU vonásokat mutató, serdülókorú fiúk itt is csökkent érzelmi reakciót mutattak a szomorúságot kifejezố filmjelenetekre (de Wied és mtsai, 2012). Ezek az eredmények alátámasztják tehát, hogy magas CU vonások esetén a distressz jelzésekre mutatott automatikus testi reakciók is érintettek, csökkent érzelmi arousal figyelhetô meg a negatív érzelmi ingerekre. Keveset árulnak el viszont a kiváltott érzelmi élmény kellemes vagy kellemetlen voltáról, vagyis annak érzelmi töltetérôl (lásd fentebb a Szubjektív érzelmi reaktivitás alfejezetet).

\section{ÖSSZEGZÉS ÉS KORLÁTOK}

A fenti empirikus vizsgálatok alapján megállapítható, hogy a magas pszichopátiás vonásokkal jellemezhetố fiatalok sajátos zavart mutatnak a negatív, különösen a distreszszel kapcsolatos jelzések (leginkább a félelem, illetve a szomorúság) feldolgozásában, legyen szó arcokról, hangokról vagy testtartással kifejezett érzelmi ingerekrôl. A pszichopátiás vonásokkal járó affektív zavar tehát nem magyarázható pusztán a tekintetre irányuló figyelmi válasz deficitjével (Dadds és mtsai, 2011). Azok a fiatalok, akik magas rideg-érzéketlen vonásokat mutatnak, a másokon látott distressz jelzésekre „vakok”, ami a figyelemelôttes feldolgozásban is megmutatkozik (pl. Kimonis és mtsai, 2008; Sylvers, Brennan és Lilienfeld, 2011; Viding és mtsai, 2012). Mindez pedig ellentmond annak a megközelítésnek is, mely a magasabb szintú, tudatos figyelmi folyamatok deficitjét hangsúlyozza (Newman és Lorenz, 2003).

Úgy tûnik, hogy mások distresszét látva nem alakul ki bennünk spontán empatikus válasz, ami könnyebben vezethet erôszakos viselkedéshez (proaktív agresszióhoz), idôvel pedig a morális fejlôdésük is zavart szenvedhet (Bird és Viding, 2014; Blair, Mitchell és Blair, 2005). Az ismertetett vizsgálatok alapján ez a sajátos érzelmi zavar az amygdala csökkent aktivitásához köthetô, amely összhangban áll azokkal a kutatási 
eredményekkel, amelyek felnôtt pszichopaták esetében is az amygdala alulmúködését találták (Decety, Skelly, Yoder és Kiehl, 2014; DeLisi, Umphress és Vaughn, 2009; Dolan és Fullam, 2009), illetve azzal a megfigyeléssel, hogy az amygdala léziója elsôsorban a félelmi ingerek feldolgozási zavarához vezet (Adolphs és mtsai, 1999, 2005; Scott és mtsai, 1997).

A fiatalkori pszichopátiás vonásokra jellemzó érzelmi deficit a félelmi válasz automatikus és tudatos összetevójében is megmutatkozik (Hoppenbrouwers és mtsai, 2016; LeDoux, 2013, 2014) (2. ábra). Számos kutatás szól amellett, hogy a magas pszichopátiás vonásokat mutató fiatalok nehezebben ismerik fel, ha valaki félelmet él át (érzelem beazonosítása). Arra is találunk bizonyítékot, hogy a distresszkeltô képeket pozitívabbnak értékelik (valencia), továbbá csökkent érzelmi reaktivitást, testi reakciót mutatnak ezekre az ingerekre (pszichofiziológiai, viselkedéses, illetve neurális válaszok formájában is).

A bemutatott kutatások mindazonáltal arra is felhívják a figyelmet, hogy a zavar nemcsak a félelem feldolgozásában mutatkozik meg. Találunk eredményt a szomorúság, a harag, a meglepôdés és az undor vonatkozásában is. Sốt, talán a fájdalom feldolgozásában a legkifejezettebb a zavar, bár ezt kevés vizsgálat mérte eddig. A pszichopátiás vonásokra jellemzô érzelmi deficit tehát több érzelem és modalitás mentén is megmutatkozhat, pervazív zavart tükröz, de leginkább mégis a félelem és a fájdalom feldolgozása érintett. Érdemes szem eloott tartani ugyanakkor, hogy a vizsgálatokban eltérô kísérleti paradigmákkal, ingeranyagokkal dolgoznak, ami még az azonos érzelmi területre vonatkozó eredmények összevetését is megnehezíti. A kutatások még a vizsgált alapérzelmek tekintetében is jelentôs eltéréseket mutatnak (pl. az összes alapérzelem feldolgozását mérték vagy csak a félelemét).

A vizsgálatok különböznek abban is, hogy kifejezetten a rideg-érzéketlen vonásokra vagy a tágabban vett pszichopátiás jellemzókre fókuszálnak (lásd Mellékletek 2. táblázat). Úgy tûnik, hogy a pszichopátia másik két faktora, azaz a nárcizmus és az impulzivitás inkább fokozottabb érzelmi feldolgozással társul, vagy épp semmilyen összefüggést nem mutat a negatív érzelmi ingerek feldolgozásával. A pszichopátia különbözô dimenzióit tehát érdemes lenne egymástól függetlenül is górcsố alá venni (Salekin, 2017). Kritikaként említhetô az is, hogy bár nincs standard határérték (cut-off) a pszichopátiás vonások kockázatának meghatározására, a fenti vizsgálatok (kevés kivétellel) a vonások mentén (pl. medián, percentilis értékek) kialakított, kis elemszámú csoportokkal dolgoznak, ami jelentôsen csökkenti az egyéni variabilitást. A korai vizsgálatok pedig az eltérések hatásméretét sem közölték.

Mindemellett az esetleges moderátor tényezók szerepe sem elhanyagolható. Az eddigi eredmények tükrében moderátor változónak tekinthetjük a viselkedési problémákat és a szorongás hiányát is. Úgy tûnik, hogy magas kockázatú fiúk esetében mindkettô erôsítheti a CU vonások és a deficites érzelmi feldolgozás közötti összefüggést (Kimonis és mtsai, 2012, 2006, 2008; Loney és mtsai, 2003; Szabó és mtsai, in press). A szorongás vizsgálata azért is kiemelten fontos, mert egyre több vizsgálat szól amellett, hogy a pszichopátiának létezik egy elsôdleges és másodlagos változata is (Szabó és mtsai, 2016), melyeket elsôsorban a szorongás szintje, illetve a gyermekkori traumák, bántalmazás megléte alapján lehet megkülönböztetni egymástól (Karpman, 1941; Porter, 1996; Skeem, Poythress, Edens, Lilienfeld és Cale, 2003). Egyelốre ke- 
vés kutatás foglalkozik azzal, hogy a pszichopátia elsôdleges és másodlagos változata különbözik-e az érzelmi feldolgozás tekintetében, mégis úgy tûnik, hogy serdülôk körében csak az alacsony szorongással jellemezhetô elsôdleges típust jellemzi deficit, a magas szorongású másodlagos csoport inkább fokozott figyelmi választ mutat a negatív érzelmi ingerekre (Bennett és Kerig, 2014; Kimonis és mtsai, 2012).

Kiemelendố továbbá, hogy a témában végzett kutatások leginkább magas kockázatú, vagyis bûnelkövetô, illetve viselkedési problémákat mutató fiúkat vizsgált. Kevés tanulmány méri a pszichopátiás vonások és az érzelmi feldolgozás kapcsolatát egészséges fiatalok mintájában, pedig a CU vonások a viselkedési problémák jelenléte nélkül is növelik a különbözố alkalmazkodási, illetve pszichiátriai problémák kockázatát (Moran és mtsai, 2009) (még ha a DSM-5-ben a viselkedési zavar egyik jelölöjeként jelennek is meg). Fontos lenne az összefüggést érzelmi problémákat mutató klinikai mintán is vizsgálni, de hiány van a lányokra koncentráló kutatásokból is, holott úgy tûnik, hogy a CU vonások magasabb szintje esetükben nem feltétlen vezet a félelmi ingerek feldolgozási zavarához (Fairchild és mtsai, 2010; Schwenck és mtsai, 2014).

\section{KITEKINTÉS}

Az ismertetett kutatásoknak fontos implikációi vannak a magas pszichopátiás vonásokat mutató gyerekek kezelésére és intervenciójára nézve is. A felnôttkori pszichopátia kezelését komoly pesszimizmus övezi (Salekin, 2002), de az érzelmek percepcióját és interpretációját hangsúlyozó, az interperszonális jelzések megértését célzó kora gyermekkori tréningek fejlesztóleg hathatnak az empátiás készségekre (Caldwell, 2011; Dadds, Cauchi, Wimalaweera, Hawes és Brennan, 2012), az agresszív viselkedés is mérséklődhet a distressz jelzések fokozásával (van Baardewijk, Stegge, Bushman és Vermeiren, 2009). Mindemellett a szorongásos zavarokban már sikeresen alkalmazott, a figyelmi torzításra fókuszáló módszerekkel (attention bias modification treatment; ABMT; Hakamata és mtsai, 2010) talán a figyelemelôttes feldolgozás is fejleszthetô lenne.

Tekintve ugyanakkor, hogy a magas viselkedési problémákkal, de alacsony CU vonásokkal jellemezhetố fiatalok ellentétes, inkább fokozott reakciót mutatnak az érzelmi ingerekre, az antiszociális fiatalok egyes alcsoportjainak megkülönböztetése is fontos feladat lenne. A CU vonások mentén meghatározott csoportok ugyanis másképp reagálhatnak az intervenciók különbözô formáira is. Korábbi kutatások alapján úgy tûnik, hogy a CU vonások az antiszociális fiataloknak egy súlyosabb, erôszakosabb alcsoportját szúrik ki (Frick és mtsai, 2014b). Ez a prediktív erô pedig fokozható lenne, ha az érzelmi feldolgozás deficitjét is mérnék.

\section{KÖSZÖNETNYILVÁNÍTÁS}

Jelen tanulmány megírását az MTA-SE-NAP B Genetikai és Agyi Képalkotó Migrén Kutatócsoport, Magyar Tudományos Akadémia, Nemzeti Agykutatási Program, Semmelweis Egyetem, KTIA_NAP_13-2-2015-0001 számú pályázata és a Nemzeti Agykutatási Program, 2017-1.2.1-NKP-2017-00002 támogatta. 


\section{IRODALOM}

Adolphs, R., Gosselin, F., Buchanan, T. W., Tranel, D., Schyns, P., \& Damasio, A. R. (2005) . A mechanism for impaired fear recognition after amygdala damage. Nature, 433(7021), 68-72.

Adolphs, R., Tranel, D., Hamann, S., Young, A. W., Calder, A. J., Phelps, E. A., ... Damasio, A. R. (1999). Recognition of facial emotion in nine individuals with bilateral amygdala damage. Neuropsychologia, 37(10), 1111-1117.

Alves, N. (2013). Recognition of static and dynamic facial expressions: A study review. Estudos de Psicologia (Natal), 18, 125-130.

American Psychiatric Association. (2013). Diagnostic and statistical manual of mental disorders, 5th edition: DSM-5 (5th ed.). Washington, D. C.: American Psychiatric Publishing.

Anastassiou-Hadjicharalambous, X., \& Warden, D. (2008). Physiologically-indexed and self-perceived affective empathy in conduct-disordered children high and low on callous-unemotional traits. Child Psychiatry and Human Development, 39(4), 503-517.

Áspán, N., Vida, P., Gádoros, J., \& Halász, J. (2013). Conduct symptoms and emotion recognition in adolescent boys with externalization problems. The Scientific World Journal, 2013. Article ID 826108

Barlow, D. H. (2000). Unraveling the mysteries of anxiety and its disorders from the perspective of emotion theory. The American Psychologist, 55(11), 1247-1263.

Baskin-Sommers, A. R., Curtin, J. J., \& Newman, J. P. (2011). Specifying the attentional selection that moderates the fearlessness of psychopathic offenders. Psychological Science, 22(2), 226-234.

Bennett, D. C., \& Kerig, P. K. (2014). Investigating the construct of trauma-related acquired callousness among delinquent youth: Differences in emotion processing. Journal of Traumatic Stress, 27(4), 415-422.

Berkowitz, L. (1993). Aggression: its causes, consequences, and control. Philadelphia: Temple University Press.

Betella, A., \& Verschure, P. F. M. J. (2016). The affective slider: A digital self-assessment scale for the measurement of human emotions. PLoS ONE, 11(2), e0148037.

Bird, G., \& Viding, E. (2014). The self to other model of empathy: Providing a new framework for understanding empathy impairments in psychopathy, autism, and alexithymia. Neuroscience and Biobehavioral Reviews, 47, 520-532.

Blair, R. J. R. (1995). A cognitive developmental approach to mortality: Investigating the psychopath. Cognition, 57(1), 1-29.

Blair, R. J. R. (1999). Responsiveness to distress cues in the child with psychopathic tendencies. Personality and Individual Differences, 27(1), 135-145.

Blair, R. J. R. (2005). Applying a cognitive neuroscience perspective to the disorder of psychopathy. Development and Psychopathology, 17(3), 865-891.

Blair, R. J. R. (2007). The amygdala and ventromedial prefrontal cortex in morality and psychopathy. Trends in Cognitive Sciences, 11(9), 387-392.

Blair, R. J. R. (2010). Psychopathy, frustration, and reactive aggression: The role of ventromedial prefrontal cortex. British Journal of Psychology, 101(3), 383-399.

Blair, R. J. R., Budhani, S., Colledge, E., \& Scott, S. (2005). Deafness to fear in boys with psychopathic tendencies. Journal of Child Psychology and Psychiatry, and Allied Disciplines, 46(3), 327-336.

Blair, R. J. R., \& Coles, M. (2000). Expression recognition and behavioural problems in early adolescence. Cognitive Development, 15(4), 421-434. 
Blair, R. J. R., Colledge, E., Murray, L., \& Mitchell, D. G. V. (2001). A selective impairment in the processing of sad and fearful expressions in children with psychopathic tendencies. Journal of Abnormal Child Psychology, 29(6), 491-498.

Blair, R. J. R., Mitchell, D., \& Blair, K. (2005). The psychopath: Emotion and the brain. Oxford, UK: Blackwell Publishing.

Bozsik, C., Körmendi, A., Inántsy-Pap, J., Pataky, N., Gádoros, J., \& Halász, J. (2013) . A reaktív/ proaktív agresszió, a rideg/érzéketlen vonások és a viselkedési problémák kapcsolata magyar serdülooknél. Psychiatria Hungarica, 28(1), 48-56.

Bradley, B. P., Mogg, K., Falla, S. J., \& Hamilton, L. R. (1998). Attentional bias for threatening facial expressions in anxiety: Manipulation of stimulus duration. Cognition and Emotion, 12(6), 737-753.

Bradley, M. M., \& Lang, P. J. (1994). Measuring emotion: The self-assessment manikin and the semantic differential. Journal of Behavior Therapy and Experimental Psychiatry, 25(1), 49-59.

Brown, H. M., Eley, T. C., Broeren, S., MacLeod, C., Rinck, M., Hadwin, J. A., \& Lester, K. J. (2014). Psychometric properties of reaction time based experimental paradigms measuring anxiety-related information-processing biases in children. Journal of Anxiety Disorders, 28(1), 97-107.

Caldwell, M. F. (2011). Treatment-related changes in behavioral outcomes of psychopathy facets in adolescent offenders. Law and Human Behavior, 35(4), 275-287.

Cassels, T. G., \& Birch, S. A. J. (2014). Comparisons of an open-ended vs. forced-choice 'mind reading' task: Implications for measuring perspective-taking and emotion recognition. PLoS ONE, 9(12).

Christian, R. E., Frick, P. J., Hill, N. L., Tyler, L., \& Frazer, D. R. (1997). Psychopathy and conduct problems in children: II. Implications for subtyping children with conduct problems. Journal of the American Academy of Child and Adolescent Psychiatry, 36(2), 233-241.

Cisler, J. M., \& Koster, E. H. W. (2010). Mechanisms of attentional biases towards threat in anxiety disorders: An integrative review. Clinical Psychology Review, 30(2), 203-216.

Cleckley, H. (1941). The mask of sanity. St. Louis, MO: C. V. Mosby.

Colden, A., Bruder, M., \& Manstead, A. S. R. (2008). Human content in affect-inducing stimuli: A secondary analysis of the international affective picture system. Motivation and Emotion, 32(4), 260-269.

Cooke, D. J., \& Michie, C. (2001). Refining the construct of psychopathy: Towards a hierarchical model. Psychological Assessment, 13(2), 171-188.

Dadds, M. R., Cauchi, A. J., Wimalaweera, S., Hawes, D. J., \& Brennan, J. (2012). Outcomes, moderators, and mediators of empathic-emotion recognition training for complex conduct problems in childhood. Psychiatry Research, 199(3), 201-207.

Dadds, M. R., El Masry, Y., Wimalaweera, S., \& Guastella, A. J. (2008). Reduced eye gaze explains "fear blindness" in childhood psychopathic traits. Journal of the American Academy of Child and Adolescent Psychiatry, 47(4), 455-463.

Dadds, M. R., Fraser, J., Frost, A., \& Hawes, D. J. (2005). Disentangling the underlying dimensions of psychopathy and conduct problems in childhood: A community study. Journal of Consulting and Clinical Psychology, 73(3), 400-410.

Dadds, M. R., Hawes, D., \& Merz, S. (2004). The UNSW facial emotion task. Sydney: University of New South Wales Department of Psychology.

Dadds, M. R., Jambrak, J., Pasalich, D., Hawes, D. J., \& Brennan, J. (2011). Impaired attention to the eyes of attachment figures and the developmental origins of psychopathy. Journal of Child Psychology and Psychiatry, and Allied Disciplines, 52(3), 238-245. 
Dadds, M. R., Perry, Y., Hawes, D. J., Merz, S., Riddell, A. C., Haines, D. J., ... Abeygunawardane, A. I. (2006). Attention to the eyes and fear-recognition deficits in child psychopathy. The British Journal of Psychiatry, 189(3), 280-281.

de Wied, M., van Boxtel, A., Matthys, W., \& Meeus, W. (2012). Verbal, facial and autonomic responses to empathy-eliciting film clips by disruptive male adolescents with high versus low callous-unemotional traits. Journal of Abnormal Child Psychology, 40(2), 211-223.

Deák, A. (2011). Érzelmek, viselkedés és az emberi agy: Az International Affective Picture System (IAPS) magyar adaptációjának és alkalmazásának lehetôségei (Doktori disszertáció). Pécsi Tudományegyetem.

Decety, J., Skelly, L., Yoder, K. J., \& Kiehl, K. A. (2014). Neural processing of dynamic emotional facial expressions in psychopaths. Social Neuroscience, 9(1), 36-49.

DeLisi, M., Umphress, Z. R., \& Vaughn, M. G. (2009). The criminology of the amygdala. Criminal Justice and Behavior, 36, 1241-1252.

Dodge, K. A. (1991). The structure and function of reactive and proactive aggression. In D. J. Pepler, \& K. H. Rubin (Ed.), The development and treatment of childhood aggression (pp. 201-218). Hillsdale, NJ: Erlbaum.

Dolan, M. C., \& Fullam, R. S. (2009). Psychopathy and functional magnetic resonance imaging blood oxygenation level-dependent responses to emotional faces in violent patients with schizophrenia. Biological Psychiatry, 66(6), 570-577.

Edens, J. F., Marcus, D. K., Lilienfeld, S. O., \& Poythress, N. G. (2006). Psychopathic, not psychopath: Taxometric evidence for the dimensional structure of psychopathy. Journal of $A b$ normal Psychology, 115(1), 131-144.

Ekman, P. (1992). An argument for basic emotions. Cognition and Emotion, 6(3-4), 169-200.

Ekman, P., \& Friesen, W. V. (1976). Measuring facial movement. Environmental Psychology and Nonverbal Behavior, 1(1), 56-75.

Fairchild, G., Hagan, C. C., Passamonti, L., Walsh, N. D., Goodyer, I. M., \& Calder, A. J. (2014). Atypical neural responses during face processing in female adolescents with conduct disorder. Journal of the American Academy of Child and Adolescent Psychiatry, 53(6), 677-687.e5.

Fairchild, G., Stobbe, Y., van Goozen, S. H. M., Calder, A. J., \& Goodyer, I. M. (2010). Facial expression recognition, fear conditioning, and startle modulation in female subjects with conduct disorder. Biological Psychiatry, 68(3), 272-279.

Fairchild, G., van Goozen, S. H., Calder, A. J., Stollery, S. J., \& Goodyer, I. M. (2009). Deficits in facial expression recognition in male adolescents with early-onset or adolescence-onset conduct disorder. Journal of Child Psychology and Psychiatry, and Allied Disciplines, 50(5), 627-636.

Frick, P. J., Bodin, S. D., \& Barry, C. T. (2000). Psychopathic traits and conduct problems in community and clinic-referred samples of children: Further development of the psychopathy screening device. Psychological Assessment, 12(4), 382-393.

Frick, P. J., Cornell, A. H., Bodin, S. D., Dane, H. E., Barry, C. T., \& Loney, B. R. (2003). Callous-unemotional traits and developmental pathways to severe conduct problems. Developmental Psychology, 39(2), 246-260.

Frick, P. J., Ray, J. V., Thornton, L. C., \& Kahn, R. E. (2014a). Annual research review: A developmental psychopathology approach to understanding callous-unemotional traits in children and adolescents with serious conduct problems. Journal of Child Psychology and Psychiatry, and Allied Disciplines, 55(6), 532-548.

Frick, P. J., Ray, J. V., Thornton, L. C., \& Kahn, R. E. (2014b). Can callous-unemotional traits enhance the understanding, diagnosis, and treatment of serious conduct problems in children and adolescents? A comprehensive review. Psychological Bulletin, 140(1), 1-57. 
Frick, P. J., \& White, S. F. (2008). Research review: The importance of callous-unemotional traits for developmental models of aggressive and antisocial behavior. Journal of Child Psychology and Psychiatry, 49(4), 359-375.

Gretton, H. M., Hare, R. D., \& Catchpole, R. E. H. (2004). Psychopathy and offending from adolescence to adulthood: A 10-year follow-up. Journal of Consulting and Clinical Psychology, $72(4), 636-645$.

Grillon, C. (2008). Models and mechanisms of anxiety: Evidence from startle studies. Psychopharmacology, 199(3), 421-437.

Guay, J.-P., Ruscio, J., Knight, R. A., \& Hare, R. D. (2007). A taxometric analysis of the latent structure of psychopathy: Evidence for dimensionality. Journal of Abnormal Psychology, 116(4), 701-716.

Hakamata, Y., Lissek, S., Bar-Haim, Y., Britton, J. C., Fox, N. A., Leibenluft, E., ... Pine, D. S. (2010). Attention bias modification treatment: A meta-analysis toward the establishment of novel treatment for anxiety. Biological Psychiatry, 68(11), 982-990.

Halász, J., Áspán, N., Bozsik, C., Gádoros, J., \& Inántsy-Pap, J. (2013). The relationship between conduct symptoms and the recognition of emotions in non-clinical adolescents. Psychiatria Hungarica, 28(2), 104-110.

Hare, R. D. (1980). A research scale for the assessment of psychopathy in criminal populations. Personality and Individual Differences, 1(2), 111-119.

Hare, R. D. (1996). Psychopathy and antisocial personality disorder: A case of diagnostic confusion. Psychiatric Times, 13, 39-40.

Hare, R. D. (2003). Hare Psychopathy Checklist-Revised (PCL-R): 2nd edition, technical manual. Toronto: Multi-Health Systems Inc.

Hare, R. D., \& Neumann, C. S. (2005). Structural models of psychopathy. Current Psychiatry Reports, 7(1), 57-64.

Hare, R. D., Strachan, C. E., \& Forth, A. E. (1993). Psychopathy and crime: A review. In K. Howells \& C. R. Hollin (szerk.), Clinical Approaches to the Mentally Disordered Offender (pp. 165-178). Chichester: Wiley.

Harris, G. T., Rice, M. E., \& Cormier, C. A. (1991). Psychopathy and violent recidivism. Law and Human Behavior, 15(6), 625-637.

Hemphill, J. F., Hare, R. D., \& Wong, S. (1998). Psychopathy and recidivism: A review. Legal and Criminological Psychology, 3(1), 139-170.

Herba, C. M., Hodgins, S., Blackwood, N., Kumar, V., Naudts, K. H., \& Phillips, M. (2007). The neurobiology of psychopathy: A focus on emotion processing. In H. Hervé \& J. C. Yuille (Eds), The psychopath: Theory research E practice (pp. 253-283). Lawrence Erlbaum Associates.

Herpers, P. C. M., Klip, H., Rommelse, N. N. J., Taylor, M. J., Greven, C. U., \& Buitelaar, J. K. (2017). Taxometric analyses and predictive accuracy of callous-unemotional traits regarding quality of life and behavior problems in non-conduct disorder diagnoses. Psychiatry Research, 253, 351-359.

Hodsoll, S., Lavie, N., \& Viding, E. (2014). Emotional attentional capture in children with conduct problems: The role of callous-unemotional traits. Frontiers in Human Neuroscience, 8,570 .

Hoffman, M. L. (1984). Empathy, its limitations, and its role in a comprehensive moral theory. In J. Gewirtz, \& W. Kurtines (Eds), Morality, moral development, and moral behavior (pp. 283-302). New York: Wiley.

Hoppenbrouwers, S. S., Bulten, B. H., \& Brazil, I. A. (2016). Parsing fear: A reassessment of the evidence for fear deficits in psychopathy. Psychological Bulletin, 142(6), 573-600.

Jackson, P. L., Meltzoff, A. N., \& Decety, J. (2005). How do we perceive the pain of others? A window into the neural processes involved in empathy. NeuroImage, 24(3), 771-779. 
Jones, A. P., Laurens, K. R., Herba, C. M., Barker, G. J., \& Viding, E. (2009). Amygdala hypoactivity to fearful faces in boys with conduct problems and callous-unemotional traits. American Journal of Psychiatry, 166(1), 95-102.

Karpman, B. (1941). On the need of separating psychopathy into two distinct clinical types: The symptomatic and the idiopathic. Journal of Criminal Psychopathology, 3, 112-137.

Karpman, B. (1949). The psychopathic delinquent child. The American Journal of Orthopsychiatry, 20(2), 223-265.

Karpman, B. (1950). Psychopathic behavior in infants and children: A critical survey of the existing concepts. American Journal of Orthopsychiatry, 21(2), 223-272.

Kimonis, E. R., Fanti, K. A., Anastassiou-Hadjicharalambous, X., Mertan, B., Goulter, N., \& Katsimicha, E. (2016). Can callous-unemotional traits be reliably measured in preschoolers? Journal of Abnormal Child Psychology, 44(4), 625-638.

Kimonis, E. R., Frick, P. J., Cauffman, E., Goldweber, A., \& Skeem, J. (2012). Primary and secondary variants of juvenile psychopathy differ in emotional processing. Development and Psychopathology, 24(3), 1091-1103.

Kimonis, E. R., Frick, P. J., Fazekas, H., \& Loney, B. R. (2006). Psychopathy, aggression, and the processing of emotional stimuli in non-referred girls and boys. Behavioral Sciences $\mathcal{E}$ the Law, 24(1), 21-37.

Kimonis, E. R., Frick, P. J., Muñoz, L. C., \& Aucoin, K. J. (2007). Can a laboratory measure of emotional processing enhance the statistical prediction of aggression and delinquency in detained adolescents with callous-unemotional traits? Journal of Abnormal Child Psychology, 35(5), 773-785.

Kimonis, E. R., Frick, P. J., Muñoz, L. C., \& Aucoin, K. J. (2008). Callous-unemotional traits and the emotional processing of distress cues in detained boys: Testing the moderating role of aggression, exposure to community violence, and histories of abuse. Development and Psychopathology, 20(2), 569-589.

Kimonis, E. R., Graham, N., \& Cauffman, E. (2017). Aggressive male juvenile offenders with callous-unemotional traits show aberrant attentional orienting to distress cues. Journal of $A b$ normal Child Psychology, 1-9.

Klapwijk, E. T., Aghajani, M., Colins, O. F., Marijnissen, G. M., Popma, A., van Lang, N. D. J., ... Vermeiren, R. R. J. M. (2016). Different brain responses during empathy in autism spectrum disorders versus conduct disorder and callous-unemotional traits. Journal of Child Psychology and Psychiatry, and Allied Disciplines, 57(6), 737-747.

Kohler, C. G., Turner, T., Stolar, N. M., Bilker, W. B., Brensinger, C. M., Gur, R. E., \& Gur, R. C. (2004). Differences in facial expressions of four universal emotions. Psychiatry Research, 128(3), 235-244.

Kruh, I. P. (2005). Historical and personality correlates to the violence patterns of juveniles tried as adults. Criminal Justice and Behavior, 32(1), 69-96.

Lamm, C., Decety, J., \& Singer, T. (2011). Meta-analytic evidence for common and distinct neural networks associated with directly experienced pain and empathy for pain. NeuroImage, 54(3), 2492-2502.

Lang, P. J., Bradley, M. M., \& Cuthbert, B. N. (1997). International Affective Picture System (IAPS). Washington, DC: NIMH Center for the Study of Emotions and Attention.

LeDoux, J. E. (2013). The slippery slope of fear. Trends in Cognitive Sciences, 17(4), 155-156.

LeDoux, J. E. (2014). Coming to terms with fear. Proceedings of the National Academy of Sciences, 111(8), 2871-2878.

Lockwood, P. L., Sebastian, C. L., McCrory, E. J., Hyde, Z. H., Gu, X., De Brito, S. A., \& Viding, E. (2013). Association of callous traits with reduced neural response to others' pain in children with conduct problems. Current Biology, 23(10), 901-905. 
Loney, B. R., Frick, P. J., Clements, C. B., Ellis, M. L., \& Kerlin, K. (2003). Callous-unemotional traits, impulsivity, and emotional processing in adolescents with antisocial behavior problems. Journal of Clinical Child $\mathcal{E}$ Adolescent Psychology, 32(1), 66-80.

Lykken, D. T. (1957). A study of anxiety in the sociopathic personality. Journal of Abnormal Psychology, 55(1), 6-10.

Lykken, D. T. (1995). The antisocial personalities (1st ed.). Hillsdale, NJ: Erlbaum.

Marsee, M. A., Silverthorn, P., \& Frick, P. J. (2005). The association of psychopathic traits with aggression and delinquency in non-referred boys and girls. Behavioral Sciences $\mathcal{E}$ the Law, 23(6), 803-817.

Marsh, A. A., Finger, E. C., Fowler, K. A., Adalio, C. J., Jurkowitz, I. T. N., Schechter, J. C., ... Blair, R. J. R. (2013). Empathic responsiveness in amygdala and anterior cingulate cortex in youths with psychopathic traits. Journal of Child Psychology and Psychiatry, and Allied Disciplines, 54(8), 900-910.

Marsh, A. A., Finger, E. C., Mitchell, D. G. V., Reid, M. E., Sims, C., Kosson, D. S., ... Blair, R. J. R. (2008). Reduced amygdala response to fearful expressions in children and adolescents with callous-unemotional traits and disruptive behavior disorders. American Journal of Psychiatry, 165(6), 712-720.

Masi, G., Milone, A., Pisano, S., Lenzi, F., Muratori, P., Gemo, I., ... Vicari, S. (2014). Emotional reactivity in referred youth with disruptive behavior disorders: The role of the callous-unemotional traits. Psychiatry Research, 220(1-2), 426-432.

McCord, W. M., \& McCord, J. (1964). The psychopath: An essay on the criminal mind. Princeton, NJ: Van Nostrand.

Michonski, J. D., \& Sharp, C. (2010). Revisiting Lynam's notion of the „fledgling psychopath”: Are HIA-CP children truly psychopathic-like? Child and Adolescent Psychiatry and Mental Health, 4(1).

Mogg, K., \& Bradley, B. P. (1998). A cognitive-motivational analysis of anxiety. Behaviour Research and Therapy, 36(9), 809-848.

Montagne, B., Kessels, R. P. C., De Haan, E. H. F., \& Perrett, D. I. (2007). The emotion recognition task: A paradigm to measure the perception of facial emotional expressions at different intensities. Perceptual and Motor Skills, 104(2), 589-598.

Moran, P., Rowe, R., Flach, C., Briskman, J., Ford, T., Maughan, B., ... Goodman, R. (2009). Predictive value of callous-unemotional traits in a large community sample. Journal of the American Academy of Child and Adolescent Psychiatry, 48(11), 1079-1084.

Muñoz, L. C. (2009). Callous-unemotional traits are related to combined deficits in recognizing afraid faces and body poses. Journal of the American Academy of Child and Adolescent Psychiatry, $48(5), 554-562$.

Muñoz, L. C., Kimonis, E. R., Frick, P. J., \& Aucoin, K. J. (2013). Emotional reactivity and the association between psychopathy-linked narcissism and aggression in detained adolescent boys. Development and Psychopathology, 25(02), 473-485.

Neumann, C. S., Hare, R. D., \& Newman, J. P. (2007). The super-ordinate nature of the psychopathy checklist-revised. Journal of Personality Disorders, 21(2), 102-117.

Neumann, C. S., Vitacco, M. J., Hare, R. D., \& Wupperman, P. (2005). Reconstruing the „reconstruction" of psychopathy: A comment on Cooke, Michie, Hart, and Clark. Journal of Personality Disorders, 19(6), 624-640.

Newman, J. P., Curtin, J. J., Bertsch, J. D., \& Baskin-Sommers, A. R. (2010). Attention moderates the fearlessness of psychopathic offenders. Biological Psychiatry, 67(1), 66-70.

Newman, J. P., \& Lorenz, A. R. (2003). Response modulation and emotion processing: Implications for psychopathy and other dysregulatory psychopathology. In R. J. Davidson, K. Scherer, 
\& H. H. Goldsmith (Eds), Handbook of Affective Sciences (pp. 1043-1067). London: Oxford University Press.

Pardini, D. A., \& Fite, P. J. (2010). Symptoms of conduct disorder, oppositional defiant disorder, attention-deficit/hyperactivity disorder, and callous-unemotional traits as unique predictors of psychosocial maladjustment in boys: Advancing an evidence base for DSM-V. Journal of the American Academy of Child and Adolescent Psychiatry, 49(11), 1134-1144.

Passamonti, L., Fairchild, G., Goodyer, I. M., Hurford, G., Hagan, C. C., Rowe, J. B., \& Calder, A. J. (2010). Neural abnormalities in early-onset and adolescence-onset conduct disorder. Archives of General Psychiatry, 67(7), 729-738.

Pataky, N., Körmendi, A., Bozsik, C., Inántsy-Pap, J., Halász, J., \& Gádoros, J. (2011). Rideg/érzéketlen vonások és interperszonális jellemzôk vizsgálata magyar serdülôknél - elsố vizsgálati eredmények. Psychiatria Hungarica, 26(6), 427-433.

Patrick, C. J. (1994). Emotion and psychopathy: Startling new insights. Psychophysiology, 31(4), 319-330.

Patrick, C. J., Bradley, M. M., \& Lang, P. J. (1993). Emotion in the criminal psychopath: Startle reflex modulation. Journal of Abnormal Psychology, 102(1), 82-92.

Patrick, C. J., Fowles, D. C., \& Krueger, R. F. (2009). Triarchic conceptualization of psychopathy: Developmental origins of disinhibition, boldness, and meanness. Development and Psychopathology, 21(3), 913-938.

Porter, S. (1996). Without conscience or without active conscience? The etiology of psychopathy revisited. Aggression and Violent Behavior, 1(2), 179-189.

Price, R. B., Kuckertz, J. M., Siegle, G. J., Ladouceur, C. D., Silk, J. S., Ryan, N. D., ... Amir, N. (2015). Empirical recommendations for improving the stability of the dot-probe task in clinical research. Psychological Assessment, 27(2), 365-376.

Salekin, R. T. (2017). Research Review: What do we know about psychopathic traits in children? Journal of Child Psychology and Psychiatry, and Allied Disciplines.

Schwenck, C., Gensthaler, A., Romanos, M., Freitag, C. M., Schneider, W., \& Taurines, R. (2014). Emotion recognition in girls with conduct problems. European Child $\mathcal{E}$ Adolescent Psychiatry, 23(1), 13-22.

Schwenck, C., Mergenthaler, J., Keller, K., Zech, J., Salehi, S., Taurines, R., ... Freitag, C. M. (2012). Empathy in children with autism and conduct disorder: Group-specific profiles and developmental aspects. Journal of Child Psychology and Psychiatry, and Allied Disciplines, 53(6), 651-659.

Scott, S. K., Young, A. W., Calder, A. J., Hellawell, D. J., Aggleton, J. P., \& Johnson, M. (1997). Impaired auditory recognition of fear and anger following bilateral amygdala lesions. Nature, 385(6613), 254-257.

Sharp, C., Van Goozen, S., \& Goodyer, I. (2006). Children's subjective emotional reactivity to affective pictures: Gender differences and their antisocial correlates in an unselected sample of 7-11-year-olds. Journal of Child Psychology and Psychiatry, 47(2), 143-150.

Skeem, J. L., Poythress, N., Edens, J. F., Lilienfeld, S. O., \& Cale, E. M. (2003). Psychopathic personality or personalities? Exploring potential variants of psychopathy and their implications for risk assessment. Aggression and Violent Behavior, 8(5), 513-546.

Stevens, D., Charman, T., \& Blair, R. J. (2001). Recognition of emotion in facial expressions and vocal tones in children with psychopathic tendencies. The Journal of Genetic Psychology, 162(2), 201-211.

Sylvers, P. D., Brennan, P. A., \& Lilienfeld, S. O. (2011). Psychopathic traits and preattentive threat processing in children: A novel test of the fearlessness hypothesis. Psychological Science, $22(10), 1280-1287$. 
Szabó, E., Galambos, A., Szabó, J., \& Kökönyei, G. (2016). A pszichopátiás személyiségzavar altípusai: Elsốdleges és másodlagos változat. Alkalmazott Pszichológia, 16(4), 49-70.

Szabó, E., Halász, J., Morgan, A., Demetrovics, Z., \& Kökönyei, G. (in press). Callous-unemotional traits and the processing of emotional stimuli among high-risk adolescents: Testing the moderating role of emotional and behavioural problems. Manuscript. Under review.

Tsuchiya, N., \& Koch, C. (2004). Continuous flash suppression. Journal of Vision, 4(8), 61-61.

van Baardewijk, Y., Stegge, H., Bushman, B. J., \& Vermeiren, R. (2009). Psychopathic traits, victim distress and aggression in children. Journal of Child Psychology and Psychiatry, 50(6), $718-725$.

Viding, E., Blair, R. J. R., Moffitt, T. E., \& Plomin, R. (2005). Evidence for substantial genetic risk for psychopathy in 7-year-olds. Journal of Child Psychology and Psychiatry, and Allied Disciplines, 46(6), 592-597.

Viding, E., Frick, P. J., \& Plomin, R. (2007). Aetiology of the relationship between callous-unemotional traits and conduct problems in childhood. British Journal of Psychiatry. Supplement, 49, s33-38.

Viding, E., Sebastian, C. L., Dadds, M. R., Lockwood, P. L., Cecil, C. A. M., De Brito, S. A., \& McCrory, E. J. (2012). Amygdala response to preattentive masked fear in children with conduct problems: The role of callous-unemotional traits. American Journal of Psychiatry, 169(10), 1109-1116.

Vincent, G. M., Vitacco, M. J., Grisso, T., \& Corrado, R. R. (2003). Subtypes of adolescent offenders: Affective traits and antisocial behavior patterns. Behavioral Sciences $\mathcal{E}$ the Law, 21(6), $695-712$.

Vitacco, M. J., Rogers, R., \& Neumann, C. S. (2003). The antisocial process screening device: An examination of its construct and criterion-related validity. Assessment, 10(2), 143-150.

White, S. F., Marsh, A. A., Fowler, K. A., Schechter, J. C., Adalio, C., Pope, K., ... Blair, R. J. R. (2012). Reduced amygdala response in youths with disruptive behavior disorders and psychopathic traits: Decreased emotional response versus increased top-down attention to nonemotional features. American Journal of Psychiatry, 169(7), 750-758.

Wiens, S., Sand, A., \& Olofsson, J. K. (2011). Nonemotional features suppress early and enhance late emotional electrocortical responses to negative pictures. Biological Psychology, 86(1), 83-89.

Wolf, S., \& Centifanti, L. C. M. (2014). Recognition of pain as another deficit in young males with high callous-unemotional traits. Child Psychiatry and Human Development, 45(4), 422-432.

Woodworth, M., \& Waschbusch, D. (2008). Emotional processing in children with conduct problems and callous/unemotional traits. Child: Care, Health and Development, 34(2), 234-244. 


\section{MEASURING EMOTIONAL PROCESSING IN YOUTH WITH PSYCHOPATHIC TRAITS: RESEARCH REVIEW}

\section{SZABÓ, EDINA - KÖKÖNYEI, GYÖNGYI}

In recent years, much attention has been paid to the emotional deficit described in psychopathy. More specifically, the affective features of psychopathic disorder (i.e., callous-unemotional or CU traits) have gained wide attention, which are believed to be a developmental precursor to adult psychopathy. Several empirical studies have shown that antisocial youth with CU traits show difficulties in processing and recognizing emotional stimuli, especially negative emotions. The aim of the present review was to describe and evaluate theories and research methods related to this emotional deficit. Although research findings are difficult to interpret due to the heterogeneity of tasks and samples used across studies, it seems that CU traits in youth are associated with atypical emotional processing that are evident at behavioural, psychophysiological and neural levels. These studies highlight the importance of prevention and early intervention for children with high CU traits that focuses on improving emotion processing deficits.

Keywords: psychopathy, callous-unemotional (CU) traits, emotional processing, childhood 


\section{MELLÉKLETEK}

2. táblázat. Áttekintô táblázat a tanulmányban ismertetett vizsgálatokról

\begin{tabular}{|c|c|c|c|c|c|}
\hline Tanulmány & 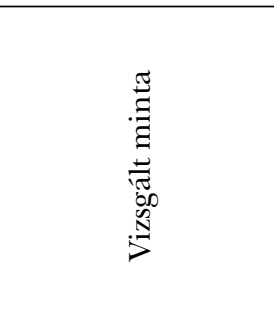 & 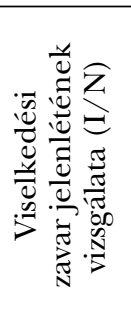 & 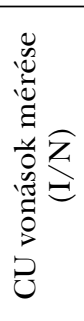 & 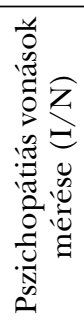 & 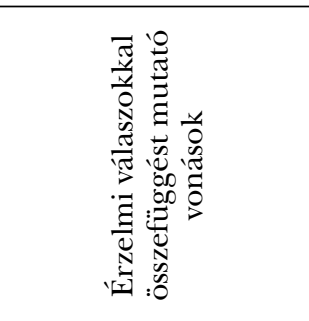 \\
\hline $\begin{array}{l}\text { Anastassiou- } \\
\text { Hadjicharalambous, } \\
\text { Warden }(2008)\end{array}$ & klinikai és kontroll & I & I & $\mathrm{N}$ & CU vonások \\
\hline Blair (1999) & $\begin{array}{l}\text { klinikai és kontroll } \\
\text { (csak fiúk) }\end{array}$ & I & $\mathrm{N}$ & I & $\begin{array}{l}\text { Összesített } \\
\text { pszichopátiás vonások }\end{array}$ \\
\hline Blair, Coles (2000) & normatív & $\mathrm{N}$ & I & I & $\begin{array}{l}\text { Összesített } \\
\text { pszichopátiás vonások }\end{array}$ \\
\hline $\begin{array}{l}\text { Blair és mtsai } \\
\text { (2001) }\end{array}$ & $\begin{array}{l}\text { klinikai } \\
\text { (csak fiúk) }\end{array}$ & I & I & I & $\begin{array}{l}\text { Összesített } \\
\text { pszichopátiás vonások }\end{array}$ \\
\hline $\begin{array}{l}\text { Blair, Budhani és } \\
\text { mtsai (2005) }\end{array}$ & klinikai (csak fiúk) & I & I & I & $\begin{array}{l}\text { Összesített } \\
\text { pszichopátiás vonások }\end{array}$ \\
\hline $\begin{array}{l}\text { Dadds és mtsai } \\
\text { (2006) }\end{array}$ & $\begin{array}{l}\text { normatív (csak } \\
\text { fiúk) }\end{array}$ & I & I & $\mathrm{N}$ & CU vonások \\
\hline $\begin{array}{l}\text { Dadds és mtsai } \\
\text { (2008) }\end{array}$ & $\begin{array}{l}\text { normatív (csak } \\
\text { fiúk) }\end{array}$ & I & I & I & CU vonások \\
\hline $\begin{array}{l}\text { de Wied és mtsai } \\
(2012)\end{array}$ & $\begin{array}{l}\text { klinikai és norma- } \\
\text { tív (csak fiúk) }\end{array}$ & I & I & I & CU vonások \\
\hline $\begin{array}{l}\text { Fairchild és mtsai } \\
\text { (2009) }\end{array}$ & $\begin{array}{l}\text { búnelkövetô és } \\
\text { kontroll } \\
\text { (csak fiúk) }\end{array}$ & I & I & I & $\begin{array}{l}\text { Összesített } \\
\text { pszichopátiás } \\
\text { vonások, } \\
\text { CU vonások }\end{array}$ \\
\hline $\begin{array}{l}\text { Fairchild és mtsai } \\
(2010)\end{array}$ & $\begin{array}{l}\text { búnelkövetô és } \\
\text { kontroll } \\
\text { (csak lányok) }\end{array}$ & I & I & I & $\begin{array}{l}\text { Összesített } \\
\text { pszichopátiás } \\
\text { vonások, } \\
\text { CU vonások }\end{array}$ \\
\hline $\begin{array}{l}\text { Fairchild és mtsai } \\
\text { (2014) }\end{array}$ & $\begin{array}{l}\begin{array}{l}\text { búnelkövetô és } \\
\text { kontroll } \\
\text { (csak lányok) }\end{array} \\
\end{array}$ & I & I & I & CU vonások \\
\hline $\begin{array}{l}\text { Frick és mtsai } \\
(2003)\end{array}$ & normatív & I & I & $\mathrm{N}$ & CU vonások \\
\hline $\begin{array}{l}\text { Hodsoll és mtsai } \\
\text { (2014) }\end{array}$ & $\begin{array}{l}\text { klinikai } \\
\text { (csak fiúk) }\end{array}$ & $\mathrm{I}$ & $\mathrm{I}$ & $\mathrm{N}$ & CU vonások \\
\hline $\begin{array}{l}\text { Jones és mtsai } \\
(2009)\end{array}$ & $\begin{array}{l}\text { normatív } \\
\text { (csak fiúk) }\end{array}$ & I & I & $\mathrm{N}$ & CU vonások \\
\hline
\end{tabular}




\begin{tabular}{|c|c|c|c|c|c|}
\hline Tanulmány & 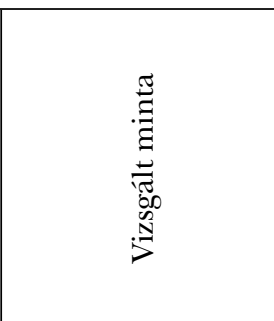 & 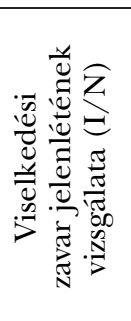 & 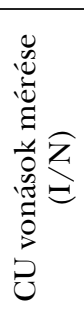 & 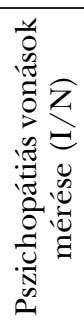 & 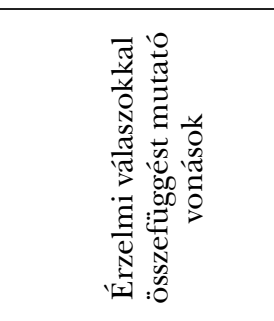 \\
\hline $\begin{array}{l}\text { Kimonis és mtsai } \\
(2006)\end{array}$ & normatív & I & I & I & $\begin{array}{l}\text { Összesített pszicho- } \\
\text { pátiás vonások, } \\
\text { CU vonások }\end{array}$ \\
\hline $\begin{array}{l}\text { Kimonis és mtsai } \\
(2008)\end{array}$ & \begin{tabular}{|l|}
$\begin{array}{l}\text { búnelkövetô } \\
\text { (csak fiúk) }\end{array}$ \\
\end{tabular} & $\mathrm{I}$ & $\mathrm{I}$ & $\mathrm{N}$ & CU vonások \\
\hline $\begin{array}{l}\text { Kimonis és mtsai } \\
\text { (2012) }\end{array}$ & $\begin{array}{l}\text { bûnelkövetố } \\
\text { (csak fiúk) }\end{array}$ & $\mathrm{N}$ & I & I & $\begin{array}{l}\text { Összesített pszicho- } \\
\text { pátiás vonások }\end{array}$ \\
\hline $\begin{array}{l}\text { Kimonis és mtsai } \\
(2016)\end{array}$ & $\begin{array}{l}\text { nevelóotthonban } \\
\text { éló és kontroll }\end{array}$ & I & I & $\mathrm{N}$ & CU vonások \\
\hline $\begin{array}{l}\text { Kimonis és mtsai } \\
(2017)\end{array}$ & \begin{tabular}{|l}
$\begin{array}{l}\text { búnelkövetô } \\
\text { (csak fiúk) }\end{array}$ \\
\end{tabular} & I & I & $\mathrm{N}$ & CU vonások \\
\hline $\begin{array}{l}\text { Klapwijk és mtsai } \\
\text { (2016) }\end{array}$ & $\begin{array}{l}\text { búnelkövetố, klini- } \\
\text { kai és kontroll } \\
\text { (csak fiúk) }\end{array}$ & I & I & $\mathrm{N}$ & CU vonások \\
\hline $\begin{array}{l}\text { Lockwood és mtsai } \\
\text { (2013) }\end{array}$ & $\begin{array}{l}\text { normatív } \\
\text { (csak fiúk) }\end{array}$ & I & I & $\mathrm{N}$ & CU vonások \\
\hline $\begin{array}{l}\text { Loney és mtsai } \\
\text { (2003) }\end{array}$ & \begin{tabular}{|l} 
búnelkövetố \\
(csak fiúk)
\end{tabular} & I & I & I & $\begin{array}{l}\text { CU vonások, } \\
\text { impulzivitás }\end{array}$ \\
\hline $\begin{array}{l}\text { Marsh és mtsai } \\
\text { (2008) }\end{array}$ & klinikai és kontroll & $\mathrm{I}$ & $\mathrm{I}$ & I & $\begin{array}{l}\text { Összesített pszicho- } \\
\text { pátiás vonások, } \\
\text { CU vonások }\end{array}$ \\
\hline $\begin{array}{l}\text { Marsh és mtsai } \\
(2013)\end{array}$ & klinikai és kontroll & I & $\mathrm{N}$ & I & $\begin{array}{l}\text { Összesített pszicho- } \\
\text { pátiás vonások }\end{array}$ \\
\hline $\begin{array}{l}\text { Masi és mtsai } \\
(2014)\end{array}$ & klinikai és kontroll & I & I & $\mathrm{N}$ & CU vonások \\
\hline $\begin{array}{l}\text { Michonski, Sharp } \\
\text { (2010) }\end{array}$ & normatív & I & I & I & CU vonások \\
\hline Muñoz (2009) & $\begin{array}{l}\text { normatív } \\
\text { (csak fiúk) }\end{array}$ & I & I & $\mathrm{N}$ & CU vonások \\
\hline $\begin{array}{l}\text { Muñoz és mtsai } \\
\text { (2013) }\end{array}$ & \begin{tabular}{|l|}
$\begin{array}{l}\text { búnelkövetố } \\
\text { (csak fiúk) }\end{array}$ \\
\end{tabular} & I & I & I & Nárcizmus \\
\hline $\begin{array}{l}\text { Schwenck és mtsai } \\
\text { (2012) }\end{array}$ & $\begin{array}{l}\text { klinikai és kontroll } \\
\text { (csak fiúk) }\end{array}$ & I & I & $\mathrm{N}$ & CU vonások \\
\hline $\begin{array}{l}\text { Schwenck és mtsai } \\
\text { (2014) }\end{array}$ & $\begin{array}{l}\text { klinikai és kontroll } \\
\text { (csak lányok) }\end{array}$ & I & I & $\mathrm{N}$ & CU vonások \\
\hline $\begin{array}{l}\text { Sharp és mtsai } \\
(2006)\end{array}$ & normatív & I & I & I & $\begin{array}{l}\text { Összesített pszicho- } \\
\text { pátiás vonások }\end{array}$ \\
\hline $\begin{array}{l}\text { Stevens és mtsai } \\
(2001)\end{array}$ & \begin{tabular}{|l}
$\begin{array}{l}\text { klinikai } \\
\text { (csak fiúk) }\end{array}$ \\
\end{tabular} & I & I & I & $\begin{array}{l}\text { Összesített pszicho- } \\
\text { pátiás vonások }\end{array}$ \\
\hline $\begin{array}{l}\text { Sylvers és mtsai } \\
(2011)\end{array}$ & $\begin{array}{l}\text { normatív } \\
\text { (csak fiúk) }\end{array}$ & I & I & I & CU vonások \\
\hline
\end{tabular}




\begin{tabular}{|c|c|c|c|c|c|}
\hline Tanulmány & 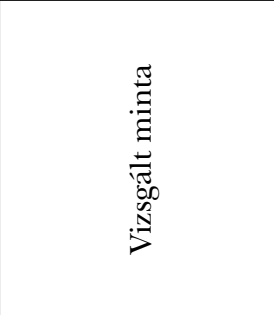 & 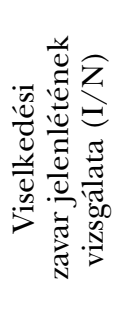 & 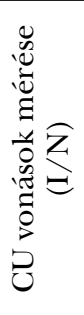 & 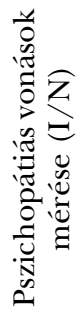 & 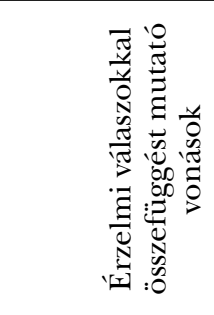 \\
\hline $\begin{array}{l}\text { Szabó és mtsai } \\
\text { (in press) }\end{array}$ & $\begin{array}{l}\text { bûnelkövetô és } \\
\text { nevelôotthonban } \\
\text { élô (csak fiúk) }\end{array}$ & $\mathrm{I}$ & $\mathrm{I}$ & $\mathrm{N}$ & CU vonások \\
\hline $\begin{array}{l}\text { Viding és mtsai } \\
(2012)\end{array}$ & $\begin{array}{l}\text { normatív } \\
\text { (csak fiúk) }\end{array}$ & $\mathrm{I}$ & $\mathrm{I}$ & $\mathrm{N}$ & CU vonások \\
\hline $\begin{array}{l}\text { White és mtsai } \\
(2012)\end{array}$ & klinikai és kontroll & I & I & $\mathrm{N}$ & CU vonások \\
\hline $\begin{array}{l}\text { Wolf, Centifanti } \\
(2014)\end{array}$ & \begin{tabular}{|l|} 
klinikai \\
(csak fiúk)
\end{tabular} & $\mathrm{I}$ & I & $\mathrm{N}$ & CU vonások \\
\hline $\begin{array}{l}\text { Woodworth, Wasch- } \\
\text { busch (2008) }\end{array}$ & klinikai & I & I & $\mathrm{N}$ & CU vonások \\
\hline
\end{tabular}

Megjegyzés: Jelen táblázat kizárólag a tanulmányban hivatkozott vizsgálatokat foglalja össze, nem célja szisztematikus áttekintést nyújtani a témával foglalkozó valamennyi kutatásról.

$C U$ : rideg-érzéketlen, I: igen, N: nem. 